\title{
High-Pressure Coal Fuel Processor Development
}

Final Report

M. L. Greenhalgh

Work Performed Under Contract No.: DE-AC21-88MC251441

\author{
For \\ U.S. Department of Energy \\ Office of Fossil Energy \\ Morgantown Energy Technology Center \\ P.0. Box 880 \\ Morgantown, West Virginia 26507-0880
}

\author{
By \\ Caterpillar Inc. \\ 100 NE Adams Street \\ Peoria, nlinois 61629
}

December 1992 
Table of Contents

LIST OF FIGURES \& TABLES

iii

LIST OF TECHINICAL PAPERS

iv

EXECUTTVE SUMMARY

INTRODUCTION 2

BACKGROUND 2

SUBTASK 2.1 - SYSTEM DESIGN :- $\quad 4$

Subtask 2.1.1 - Engine Concept Design 4

Subtask 2.1.2 - Fuel Processor Design $\quad 8$

Removable Canister Design Concept $\quad 8$

Multiple Valve Design Concept 11

Guide Tube Design Concept $\quad 14$

Design Concepts Assessment $\quad 14$

Subtask 2.1.3 - Integrated System Design 17

Analytical System Model 17

Air Compressor Concepts 23

System Control Concept 23

Locomotive Installation Concept 28

$\begin{array}{ll}\text { SUMMARY } & 30\end{array}$ 


\section{List of Figures \& Tables}

\section{Figures}

1. Coal Fueled Diesel System Schematic

2. Current Technology Fuel Processor Size vs Line-Haul Locomotives 3

3. Coal Gas Injector Concept Layout 4

4. Alternative Injector Tips

5. Removable Canister Design Concept Cross Section

6. Removable Canister Design Concept Transfer Mechanism 10

7. Multiple Valve Design Concept Cross Section 12

8. Multiple Valve Design Concept Scraper Mechanism 13

9. Guide Tube Design Concept Cross Section 15

10. Guide Tube Design Concept Resupply Mechanism 16

11. System Efficiency vs Fuel Temperature \& Pressure 17

12. System Thermal Efficiency vs Peak Cylinder Pressure 18

13. System Efficiency vs Air-to-Coal Ratio For Three Coal Types 18

14. Coal-To-Air vs Water-To-Coal Ratio: Concept Study Coal Specification 19

15. Coal-To-Air vs Water-To-Coal Ratio: Decker Subbituminous Coal 20

16. Coal-To-Air vs Water-To-Coal Ratio: Bituminous Char 20

17. Practical Operating Regions For Three Coal Specifications 21

18. Integrated System Concept Design Parameters: Engine, Fuel Proc., Coal Types 22

19. System Control Concept Modules 24

20. Engine Control Concept 25

21. Caterpillar 3600 Series Spark Ignited Natural Gas Engine Control 26

22. Fuel Processor Control Concept 27

23. Kesupply Control Concept $\quad 27$

24. Layout Of System Concept Design: Locomotive Installation 29

\section{Tables}

1. Alternative Injector Tip Features 6

2. Alternative Injector Tip Diameters \& MACH Numbers 6

3. Valve Diameter vs Injector Diameter Tradeoffs 7

4. Compressor Heat Exchanger Conditions 23 


\section{List of Technical Papers}

METC Contractors Review Meeting Papers:

1. Greenhalgh, M.L., Orr, D.R., Wen, C., Montafia, S., "Coal-Gas-Fueled Diesels for Locomotives and High Pressure Fuel Processor Design", Proceedings of the Sixth Annual Coal-Fueled Heat Engines and Gas Stream Cleanup Systems Contractors Review Meeting, March 1989, pp. 91-98.

2. Greenhalgh, M.L., "High-Pressure Coal Fuel Processor Development", Seventh Annual Coal-Fueled Heat Engines and Gas Stream Cleanup Systems Contractors Review Meeting, March 26-28, 1990.

3. Greenhalgh, M.L., "High-Pressure Coal Fueled Processor Development", Eighth Annual Coal-Fueled Heat Engines and Gas Stream Cleanup Systems Contractors Review Meeting, July 16-18, 1991.

4. Greenhalgh, M.L., "High-Pressure Coal Fuel Processor Development", Ninth Annual CoalFueled Heat Engines, Advanced Pressurized Fluidized Bed Combustion (PFBC) and Gas Stream Cleanup Systems Contractors Review Meeting, October 27-29, 1992.

ASME Energy-Sources Technology Conference and Exhibition (ETCE) Papers:

1. Greenhalgh, M.L., "High-Pressure Coal Fuel Processor/Engine Development", Coal-Fueled Diesel Engines, ASME ICE-Vol.14, 1991, pp. 49-55.

2. Greenhalgh, M.L., "Preliminary Test Data and Systems Analysis of a High-Pressure Coal Fuel Processor/Engine System Concept", Coal Fueled Diesel Engines, ASME ICE-Vol. 16, 1992, pp. 17-23. 
DE-AC21-88MC25141

\title{
High-Pressure Coal Fuel Processor Development
}

\author{
- Final Technical Report -
}

\section{EXECUTIVE SUMMARY}

Caterpillar shares DOE/METC interest in demonstrating the technology required to displace petroleum-based engine fuels with various forms of low cost coal. Current DOE/METC programs on mild gasification and coal-water-slurries are addressing two approaches to this end. Engine and fuel processor system concept studies by Caterpillar have identified a third, potentially promising, option.

This option includes high-pressure fuel processing of run-of-the-mine coal and direct injection of the resulting low-Btu gas stream into an ignition assisted, high compression ratio diesel engine. The compactness and predicted efficiency of the system make it suitable for application to linehaul railroad locomotives.

Caterpillar was contracted by the Morgantown Energy Technology Center to conduct research needed to establish the technical feasibility of the proposed integrated engine and fuel processor system concept. The project consisted of two major tasks: Task 1 - Proof-of-Principle Testing and Task 2 - Concept Design and Analysis.

Task 1 had two subtasks in which the technical feasibility of the engine combustion and fuel processor subsystems were demonstrated (see 'íopical Report, 11/30/92). In Task 2, an integrated engine/fuel processor system concept was designed and analyzed and is the subject of this report.

Two overall conclusions resulted from Task 1 . First, direct injected, ignition assisted Diesel cycle engine combustion systems can be suitably modified to efficiently utilize low-Btu gas fuels. Second, high pressure gasification of selected run-of-the-mine coals in batch-loaded fuel processors is feasible. These two findings, taken together, significantly reduce the perceived technical risks associated with the further development of the proposed coal gas fueled Diesel cycle power plant concept.

The significant conclusions from Task 2 were:

- An engine concept, derived from a Caterpillar 3600 series engine, and a fuel processor concept, based on scaling up a removable-canister configuration from the test rig, appear feasible.

- Although the results of this concept study are encouraging, further, full-scale component research and development are required before attempting a full-scale integrated system demonstration effort.

The proof-of-principle test results from Task $\perp$ and the system concept design and analysis results from Task 2 indicate that the compactness and predicted efficiency of the system concept make it suitable for application to line-haul locomotives. The successful conclusion of this program enables further component deve' Jpment work and full-scale system demonstrations of this potentially important technology. However, funding for further research on this concept has been terminated based on the expectation that natural gas prices will be extremely low, relative to coal, for the next two decades. 


\section{INTRODUCTION}

The work completed in Task 1 - Proof-of-Principle Testing is briefly summarized here and discussed in detail in the Test Program Topical Report.

In Subtask 1.1 Engine Feasibility, research was conducted to establish the technical feasibility of ignition and stable combustion of directly injected, 3,000 psi, low-Btu gas with glow plug ignition assist at diesel engine compression ratios. This objective was accomplished by designing, fabricating, testing and analyzing the combustion performance of synthesized low-Btu coal gas in a single-cylinder test engine combustion rig at the Caterpillar Technical Center in Mossville, Il.

In Stubtask 1.2 Fuel Processor Feasibility, research was conducted to establish the technical feasibility of air-blown, fixed-bed, high-pressure coal fuel processing at up to 3,000 psi operating pressure, incorporating in-bed sulfur and particulate capture. This objective was accomplished by designing, fabricating, testing and analyzing the performance of bench-scale processors located at Coal Technology Corporation (subcontractor) facilities in Bristol, Virginia.

These two subtasks were carried out at widely separated locations. They were, however, interdependent in that the composition of the synthetic coal gas used to fuel the combustion rig was adjusted to reflect the range of exit gas compositions being produced on the fuel processor rig.

The remainder of this report discusses in detail the results from Task 2 - Concept Design and Analysis.

\section{BACKGROUND}

DOE/METC has a major interest. in demonstrating the technology required to displace petroleum-based engine fuels with various forms of minimally processed, low cost coal. Programs on coal-water-slurries, dry powders, and mild gasification coal liquids are addressing various approaches to this end.

Caterpillar experience with solid and liquid forms of coal have not been encouraging. Dry and slurry forms produce engine wear rates several hundred times more severe than currently acceptable. Even highly beneficiated coals are too abrasive. Known processes for producing liquid fuels from coal exist but, despite extensive research and development efforts, all remain very costly for commercial application. The remaining form is coal gas from coal gasification.

Engine and fuel processor system concept studies conducted by Caterpillar prior to this contract have identified a potentially promising option. This option includes high-pressure fuel processing of run-of-the-mine coal and direct injection of the resulting low Btu gas stream into an ignition assisted, high compression ratio Diesel cycle engine. The compactness and predicted thermal efficiency of the proposed system concept make it suitable for application to line-haul railroad locomotives.

In fact, these studies show a railroad locomotive to be an ideal target application. Many railroads have ready access to coal and an opportunity to realize significant savings in operating costs. In line-haul railroad service the cost of fuel is large enough, $75 \%$ of operating costs, to provide a strong incentive for the use of cheaper coal. A case in point is the Burlington Northern Railroad which consumes 300 million gallons of diesel fuel per year and derives one quarter of its revenue from the hauling of coal. 
The coal-gas-fueled diesel system concept (patented) is shown schematically in Figure 1. To obtain high engine efficiency, the fuel processor needs to produce coal gas at high pressure for direct injection into the diesel engine near top-dead-center of the compression stroke. Operating pressures up to $3000 \mathrm{psi}$ are required to inject and mix fuel gas with compressed, in-cylinder combustion air that has been inducted and compressed in the conventional manner. These requirements led to the selection of a fixed-bed gasifier for the fuel processor. A preliminary systems analysis indicated that optimum overall system thermal efficiency would be obtained with direct, engine-driven compressors supplying compressed air and water to the fuel-processor.

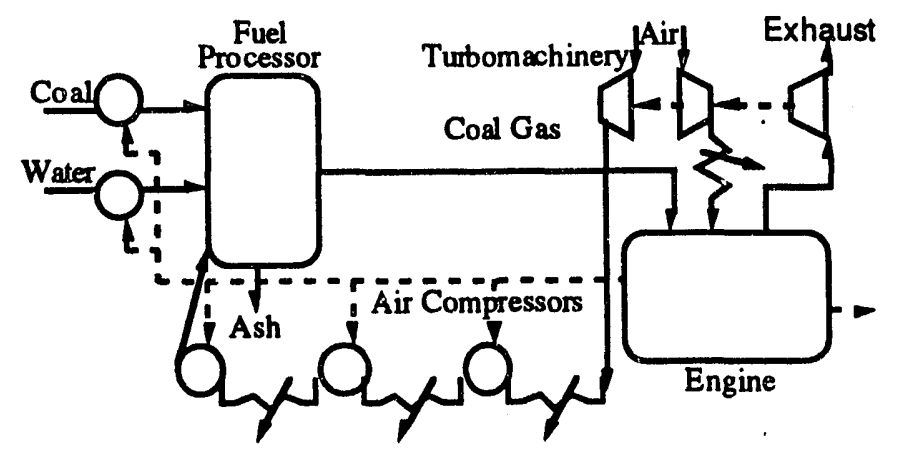

Figure 1. Coal Fueled Diesel System Schematic

In order to reduce the fuel processor size to meet locomotive installation consiraints (Figure 2) two features are necessary: high pressure operation and in-bed sulfur and particulate capture. Existing lock-hopper technology limits fixed-bed gasifier operating pressures to $1500 \mathrm{psi}$. A compact, recurrently batch-loaded reactor vessel module concept was identified to satisfy requirements for 3000 psi operating pressure, in-bed sulfur and particulate capture and locomotive packaging.

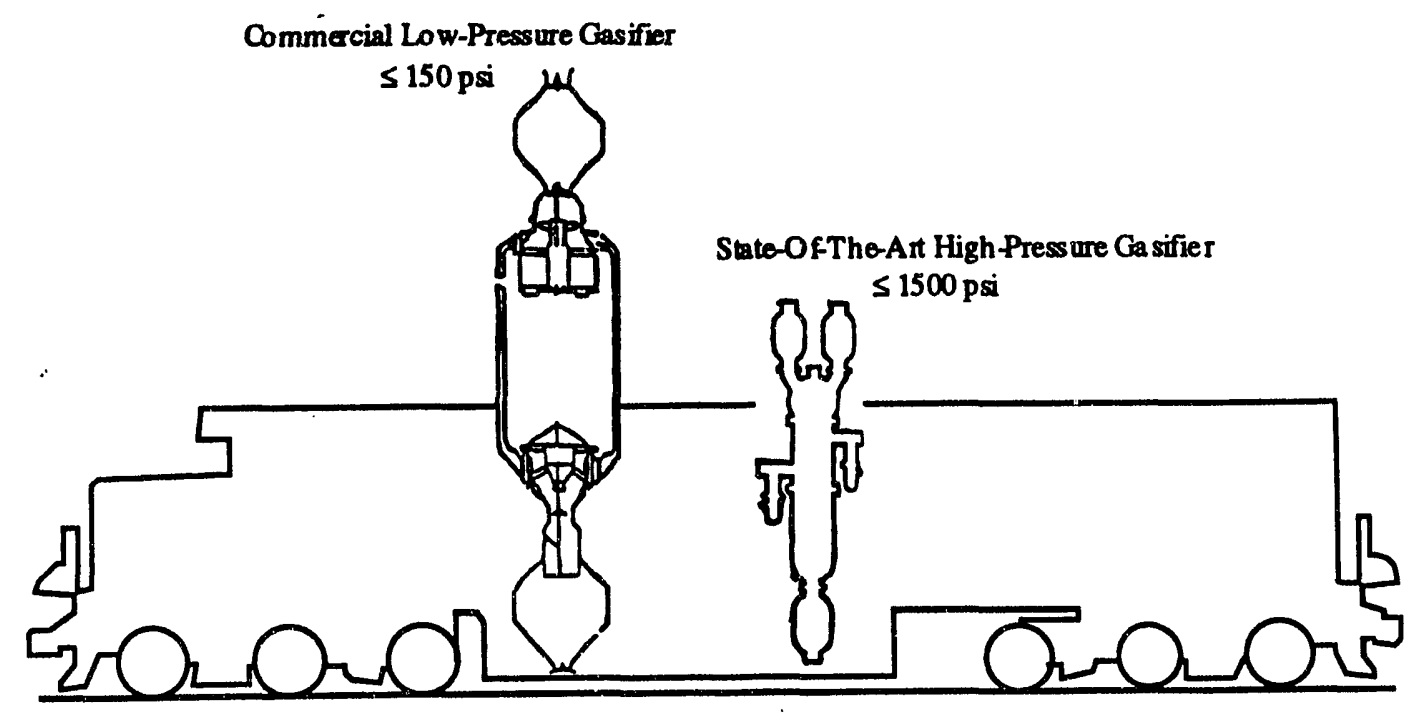

Figure 2. Current Technology Fuel Processor Size vs Line-Haul Locomotives 


\section{SUBTASK 2.1 - SYSTEM DESIGN}

The objective of this subtask, per Modification A010 of the contract Statement of Work, was to define the major components, subsystems and overall configuration of the coal-gas-fueled diesel locomotive concept including design options to bridge the technical research and development gaps identified in Caterpillar's original concept analysis. This objective was accomplished by defining design options for the engine, the fuel processor and the integrated system as discussed in the following sections.

\section{Subtask 2.1.1 - Engine Concept Design}

The objective of this subtask was to provide layouts of engine design options addressing technical research and development gaps inhibiting commercialization of the coal-gas-fueled engine. The engine concept is based on a modification of a Caterpillar 3612 series engine. The major feature of the coal fueled engine concept that significantly departs from the 3600 series engine configuration is the coal gas fuel injector and the cylinder head valving and porting arrangements. The concept design for this component assumes a low energy content gas $(=100 \mathrm{Btu} / \mathrm{SCF})$ at high temperature $(1000 \%)$ and high pressure (3000 psi).

The injector (Figure 3) was designed for $0.044 \mathrm{lbm}$ of coal gas per firing cycle within 35 crankangle degrees (CA) at 1060 engine revolutions per minute (RPM). The coal gas is brought to the injector via a cast passage in the lower third of the cylinder head. Both the gas supply passage and the injector tip are air-gap insulated to protect the cylinder head and to preserve the thermal energy of the gas. The flow of the coal gas into the combustion chamber is controlled by a check valve and an orifice in the injector tip.

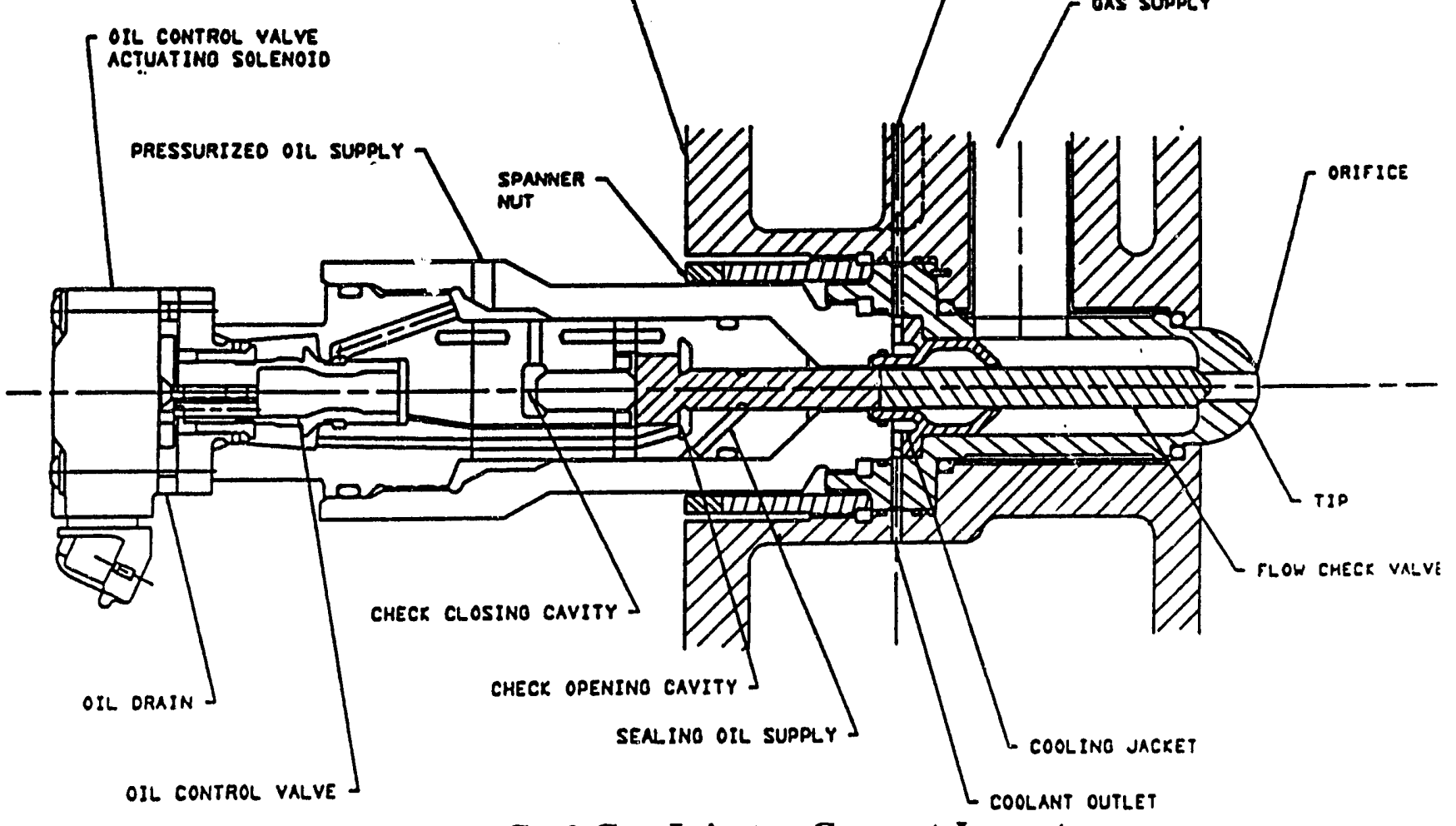

Figure 3. Coal Gas Injector Concept Layout 
The motion of the check valve is generated by a hydraulic actuator, powered by $3000 \mathrm{psi}$ oil. The check valve is held closed by constant pressure in the check-closing cavity. The check valve is operated by alternately supplying and dumping pressure in the check-opening cavity. These pressure pulses are generated by the oil control valve and its actuating solenoid. These components were patterned after a Caterpillar-designed gas injector.

Preliminary calculations indicated a relatively high check-valve seating velocity $(21 \mathrm{ft} / \mathrm{sec})$. This may make it necessary to incorporate a damper in the design. If so, a dynamic simulation of the actuator would be required to guide the design work and this was beyond the scope of this contract.

The check valve stem is cooled before entering the hydraulic actuator by passing it through both a heat shield and a cooling jacket. Engine coolant flows through the cooling jacket.

Gas loss from the injector into the actuator is prevented by the use of a sealing oil. The hydraulic actuator oil is used as the sealing oil. The injector is designed so that sealing oil always leaks into the engine as the worst case.

The injector is mounted in the cylinder head against a shoulder located just above the gas supply passage and clamped in place by a spanner nut. The clamping flange has engine coolant flowing through it. The tip of the injector is sealed with radial metal C-seal.

Five different injector tip configurations were studied (Figure 4). They all share the features described above. Some require minor modifications to the specific dimensions of the actuator and the injector. The distinguishing features are listed in Table 1 . The last row contains the features of the injector used in the combustion rig tests, scaled to the bore size of Caterpillar 3600 series engines.
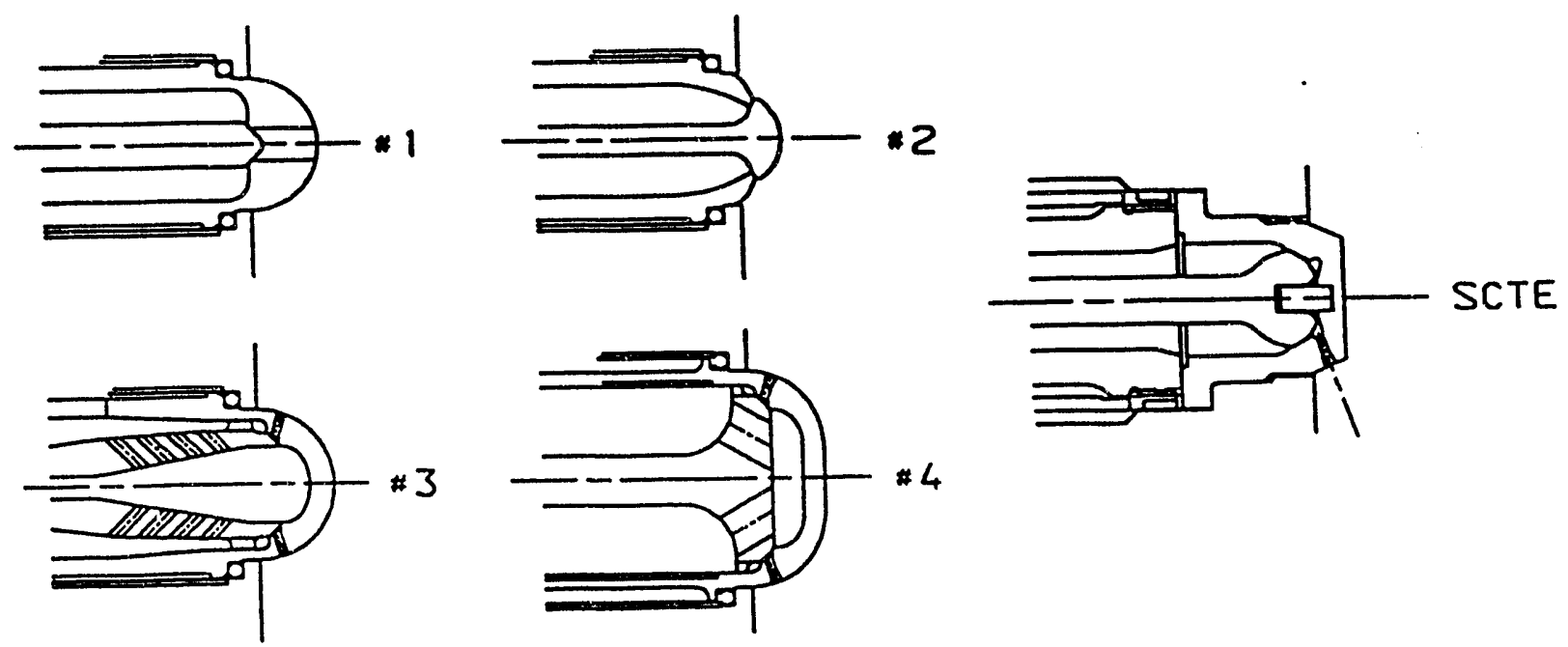

Figure 4. Alternative Injector Tips 
Table 1. Alternative Injector Tip Features

\begin{tabular}{|c|c|c|c|c|c|}
\hline$\underset{\#}{\text { Configuration }}$ & $\begin{array}{c}\text { Check } \\
\text { Configuration }\end{array}$ & $\begin{array}{l}\text { Opening } \\
\text { Direction }\end{array}$ & $\begin{array}{l}\text { Sealing } \\
\text { Diameter }\end{array}$ & $\begin{array}{c}\text { Orifice } \\
\text { Configuration }\end{array}$ & $\begin{array}{l}\text { Injector } \\
\text { Dia. }\end{array}$ \\
\hline $\begin{array}{c}1 \\
2 \\
3 \\
4 \\
\text { Scaled SCTE }\end{array}$ & $\begin{array}{c}\text { Straight } \\
\text { Cone } \\
\text { Cone } \\
\text { Flat } \\
\text { Bulb }\end{array}$ & $\begin{array}{l}\text { Inward } \\
\text { Outward } \\
\text { Inward } \\
\text { Inward } \\
\text { Inward }\end{array}$ & $\begin{array}{c}\text { Small } \\
\text { Med.Small } \\
\text { Med.Large } \\
\text { Large } \\
\text { Med.Large }\end{array}$ & $\begin{array}{l}\text { Single } \\
\text { Conical } \\
\text { Multiple } \\
\text { Multiple } \\
\text { Multiple }\end{array}$ & $\begin{array}{c}\text { Small } \\
\text { Small } \\
\text { Medium } \\
\text { Large } \\
\text { Large }\end{array}$ \\
\hline
\end{tabular}

Injector tip configuration \#1 was selected as the most desirable because of its small size, the similarity of its discharge to a conventional precombustion chamber, and its conventional check seat geometry. All the tips are significantly larger than those on equivalent-power commercial diesel engine fuel injectors because of the relatively large mass and volume of injected coal gas compared to liquid diesel fuel. The range of injector tip sizes investigated had maximum internal MACH numbers from 0.075 to 0.375 (Table 2). For reference, typical MACH numbers for air inlet ports on commercial diesel engines are about 0.25 and the injector on the synthetic coal gas combustion rig engine (SCTE) had a maximum internal MACH number of 0.100 .

Table 2. Alternative Injector Tip Diameters \& MACH Numbers

\begin{tabular}{cccccc}
\hline MACH Number $->$ & 0.075 & 0.100 & 0.150 & 0.225 & 0.375 \\
$\begin{array}{c}\text { Configuration } \\
\text { \# }\end{array}$ & $\begin{array}{c}\text { Diameter } \\
\text { in. }\end{array}$ & $\begin{array}{c}\text { Diameter } \\
\text { in. }\end{array}$ & $\begin{array}{c}\text { Diameter } \\
\text { in. }\end{array}$ & $\begin{array}{c}\text { Diameter } \\
\text { in. }\end{array}$ & $\begin{array}{c}\text { Diameter } \\
\text { in. }\end{array}$ \\
1 & 3.41 & & 2.65 & 2.21 & 1.91 \\
2 & 3.41 & & 2.65 & 2.21 & 1.91 \\
3 & 3.76 & & 2.93 & 2.44 & 2.11 \\
4 & 4.87 & & 3.79 & 3.15 & 2.72 \\
Scaled SCTE & & 4.17 & & & \\
\hline
\end{tabular}

The injector tip and check are directly exposed to hot coal gas at high pressure. This requires using high temperature materials such as Inconel 625.

The relatively large diameter of the injector encroaches on the space available for the inlet and exhaust valves, within the cylinder bore diameter. Table 3 lists the tradeoffs between number of valves, maximum valve diameter and maximum injector diameter. Given the number of valves listed in the first column, the second column lists the maximum valve diameter that is consistent with structural integrity (valve-to-liner and valve-to-valve spacings should be no less than those on a highly rated Caterpillar 3612 engine of the same bore size). The third column lists the maximum injector diameter that is consistent with minimum valve-to-injector spacing. 
Table 3. Valve Diameter vs Injector Diameter Tradeoffs

\begin{tabular}{ccc}
\hline $\begin{array}{c}\text { \# of } \\
\text { Valves }\end{array}$ & $\begin{array}{c}\text { Maximum } \\
\text { Valve Dia. } \\
\text { in. }\end{array}$ & $\begin{array}{c}\text { Injector } \\
\text { Dia. } \\
\text { in. }\end{array}$ \\
4 & 3.54 & $\leq 1.50$ \\
5 & 3.03 & $\leq 2.58$ \\
6 & 2.57 & $\leq 3.48$ \\
7 & 2.19 & $\leq 4.24$ \\
8 & 1.87 & $\leq 4.88$ \\
\hline
\end{tabular}

The last column in Table 3 shows that the injector diameter for a four-valve configuration can be no greater than 1.50" to avoid displacing total available inlet and exhaust valve area. An injector this small, delivering $0.044 \mathrm{lbm} /$ injection of coal gas would have an internal MACH number greater than the 0.375 target value (see Table 2, configuration \#1 and \#2). In other words, the coal gas fueled diesel engine in this bore size needs five valves in order to maximize the total valve flow area, given a 1.91 " diameter injector.

Conventional engine design practice would then tend to lead to the selection of a configuration with three inlet and two exhaust valves. However, the concept engine is also unusual in that the intake air mass flow is only $50 \%$ of the cylinder exhaust mass flow, since $50 \%$ of the total flow enters the cylinder through the injector as fuel. This may well dictate other than conventional distribution of valve area for optimum performance. Optimization of this feature of the engine was beyond the scope of work of this contract.

The cylinder head concept design was not taken to the point of laying out the ports due to the uncertainty in the valve flow split and, hence, the size of the injector. The port design will, however, have to be unique in that room must be allowed for the insulated gas supply passage. In the currently selected configuration, a single three-valve intake port could reside on one de of the cylinder head while two individual exhaust ports, one on each side of the gas supply passage, could reside on the other side of the cylinder head. This arrangement would keep the hot and cold passages separated. 


\section{Subtask 2.1.2 - Fuel Processor Design}

The objective of this subtask was to establish preliminary specifications for a 3000 psi fixed-bed coal fuel processor with potential for fueling suitably modified diesel engines. The fuel processor is configured to sequentially batch load and resupply its gasification section with a fresh supply of coal and granular bed filter media in order to provide the engine with a continuous flow of clean coal gas. Three concepts were investigated for mechanizing the batch loading and resupply functions. They will be referred to as the Removable Canister, Multiple Valve and Guide Tube design concepts.

All three of the design concepts utilize a fuel canister inside diameter of 10 inches with a coal charge length of 35 inches. The pressure vessels are designed for $3000 \mathrm{psi}$ internal pressure with maximum canister wall temperatures of $1800 \%$. Insulation techniques and pressure vessel materials identified in the design of the fuel processor test rig were applied in these concept designs.

\section{Removable Canister Design Concept}

In the removable canister design concept, a pressure vessel shell is lowered into position over a canister, containing the coal charge and filters, and locked into place with a breech mechanism to form a high pressure seal with the vessel seat (Figure 5). There are four of these gasification stations, each served by separate canisters. After the gasification process is completed, the pressure vessel shell is raised to clear the canister (Figure 6). The canister is then transported horizontally on a sliding tray away from the gasification station to the cleaning and refilling (resupply) station.

Each of two resupply stations service two of the four gasification stations. The pressure vessel shells are paired and counterbalanced through a chain drive (Figure 6). As one is lowered into position over its vessel seat, the other is raised from its seat to clear the canister.

Four gasification stations operate in sequence. Oxidants (air and water) are metered to the active station during gasification. The coal gas produced is routed through a second, inactive station prior to passing on to the engine. When gasification is nearly completed, oxidants are rerouted to the second station which then becomes active. The first station, no longer supplied with oxidant flow, becomes inactive and is depressurized prior to opening. The canister from this station is then transported to the resupply station. The above described sequence is then repeated between the second and third stations, then between the third and fourth stations, and so on. As the gasification process advances from station to station, the engine is supplied with a continuous supply of high pressure coal gas.

During gasification, water is injected through spray nozzles in the top of the pressure vessel shell. A set of glow plugs is used to initiate the reaction process. While single glow plugs were employed in the fuel processor rig tests, multiple glow plugs may be required to initiate a uniform flame front in these larger canisters. The internal surface of the pressure vessel shell is coated with a high temperature castable insulation (CERLITE $\& 18$ ) separated from the canister with a liner tube. The pressure vessel outer shell is cast from 17-4 PH stainless steel. 
DE-AC21-88MC25141

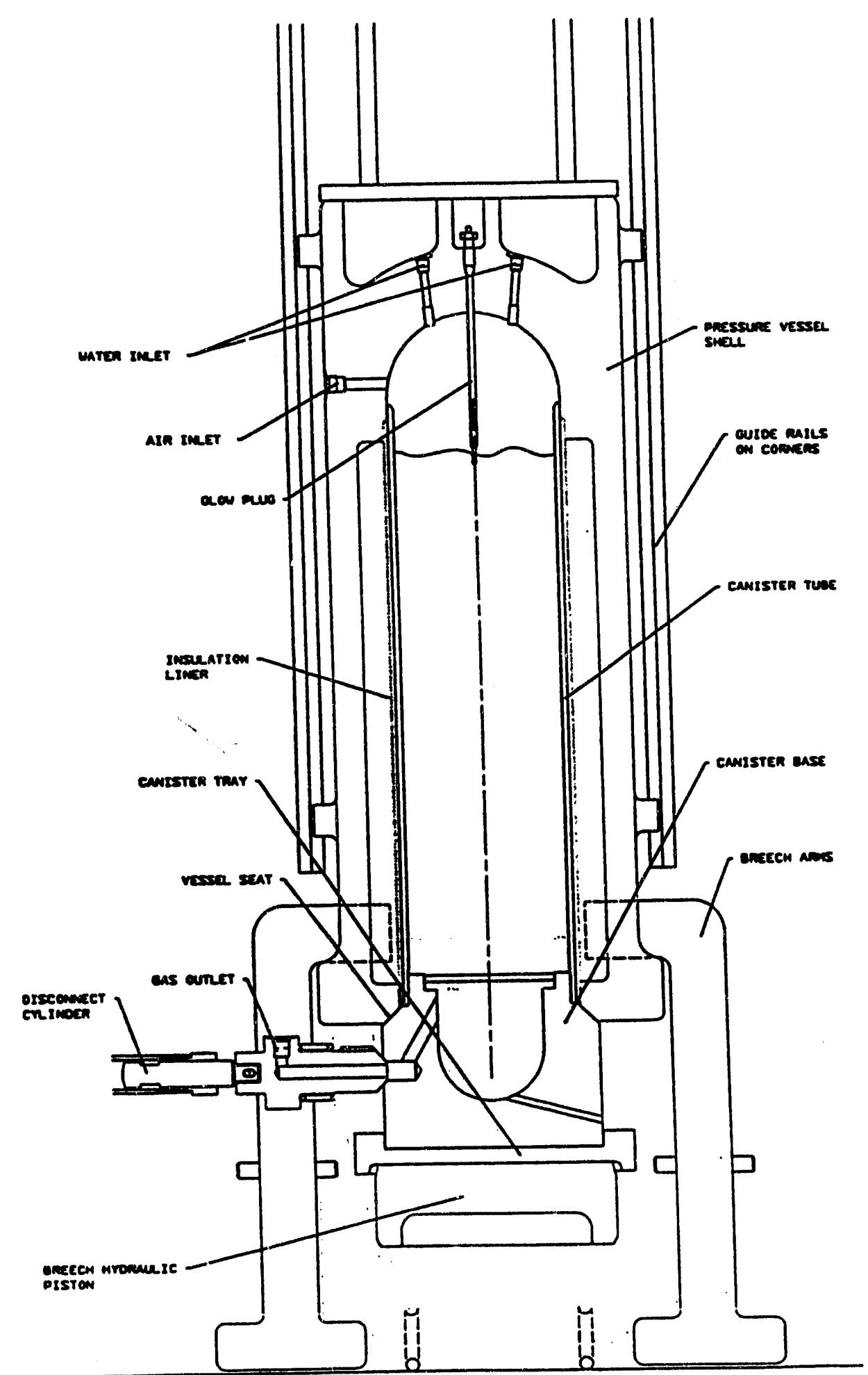

Figure 5. Removable Canister Design Concept Cross Section 


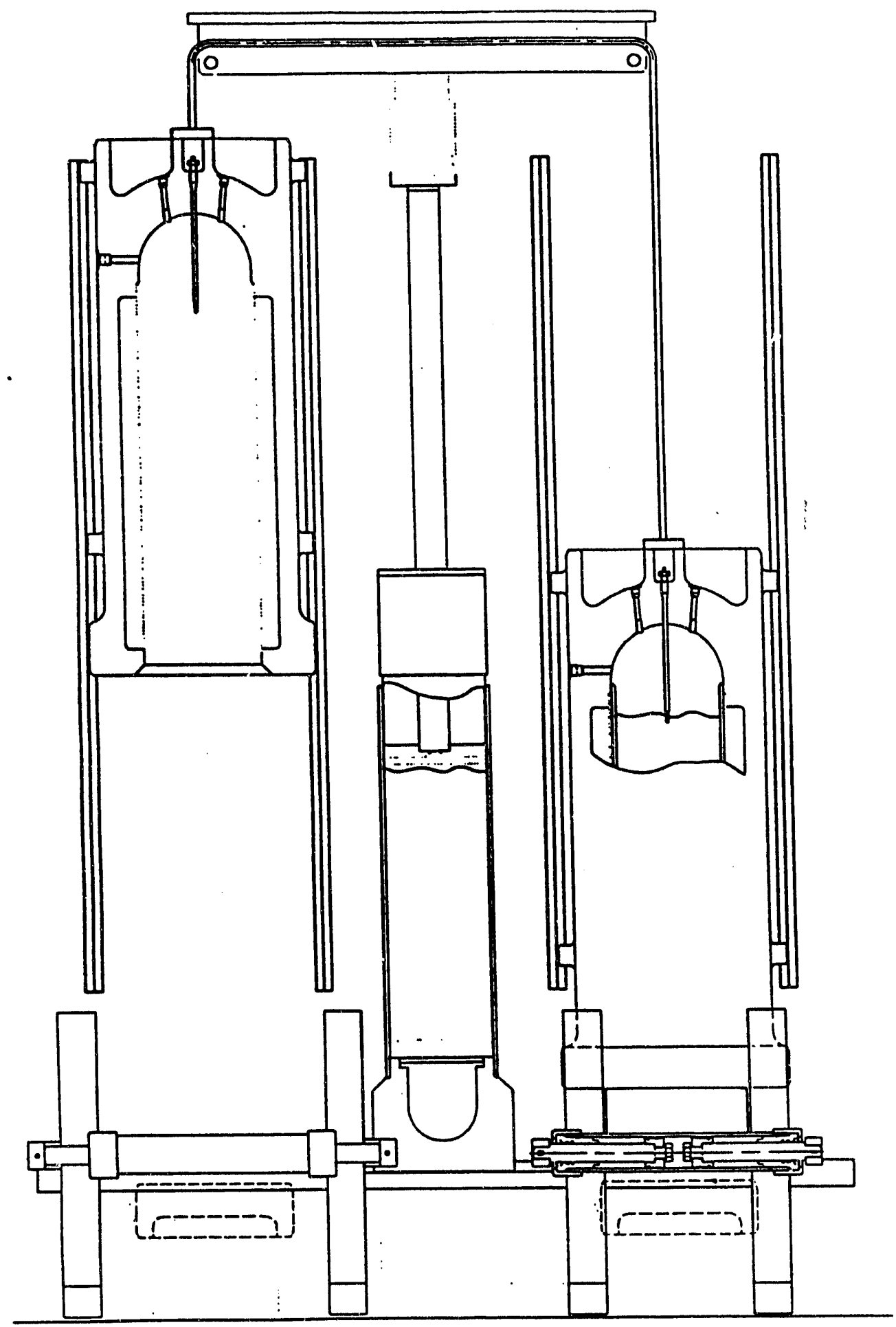

Figure 6. Removable Canister Design Concept Transfer Mechanism 
The canisters (Haynes Alloy 556 tubing) are designed to withstand the high reaction temperatures. The canister base includes a tapered valve seat that seals the 3000 psi operating pressure when clamped closed with the breech mechanism. A gas outlet valve locks the canister in place when force is applied through a disconnect cylinder. The canister base houses a support plate and a porous filter to support and hold back the granular bed filter media. A trap is provided to separate out liquid waste products. Ash and sand waste products are removed during cleaning and refilling at the resupply station.

The breech mechanism has four arms to clamp the pressure vessel shell against its base. The breech arms are positioned over the the pressure vessel shell with double acting hydraulic cylinders. A larger hydraulic piston is aligned with the center on the canister under the guide tray to supply the clamping load.

The resupply station cleaning process uses a vertical scraper drive to break up waste coal ash and sand. A rack and pinion drive raises and lowers the vacuum rube and scraper head into the fuel canister. To assist the vacuum process and back flush the porous sand filter, high pressure air is ported through an air disconnect cylinder and locking gas valve, similar to the one shown on the lower left in Figure 5. Metered amounts of coal and sand are added to the fuel canister through a cylindrical funnel shown in the center of Figure 6. This funnel keeps the the coal products from spilling during the refilling process. The vertical position of the funnel is controlled with a lift drive to sequentially open sand and coal metering gates.

This design concept has a total footprint of $45.2 \mathrm{ft}^{2}$ and a height of $11.2 \mathrm{ft}$ for the two resupply stations, the four gasification stations and the canister transfer mechanisms. The canister breech seal mechanism could possibly be reduced in size and mass by applying technology embodied in $155 \mathrm{~mm}$ cannons used in M109 artillery vehicles by the U.S. Army.

\section{Multiple Valve Design Concept}

The multiple valve design concept (Figure 7) has a fixed liner, as opposed to a removable canister, centered in a stationary pressure vessel. The pressure vessel is fitted with an upper head that contains multiple valves. The coal gas exit passages and ash/filtrate residue removal means are provided in a second housing located at the bottom of the pressure vessel.

This design concept has three gasification stations that operate in sequence to provide the engine with a continuous flow of clean coal gas. Poppet valves in the upper head structure admit high pressure air, water, coal and granular filter media. Solenoid valves port hydraulic fluid or pressurized air to valve plungers for opening the poppet valves. Water is metered into the chamber through a spray nozzle located in the upper head. A rotating scraper (Figure 8) is lowered into the gasification chamber to break up ash and filtrate residue. Ash and residue exit the reactor through a single poppet valve (Figure 7) in the bottom head structure.

Keeping the waste exit poppet valve free and clean of residue will require further concept development. The feasibility of feeding coal and granular filter media through poppet valves could be demonstrated with solids handling bench tests. 


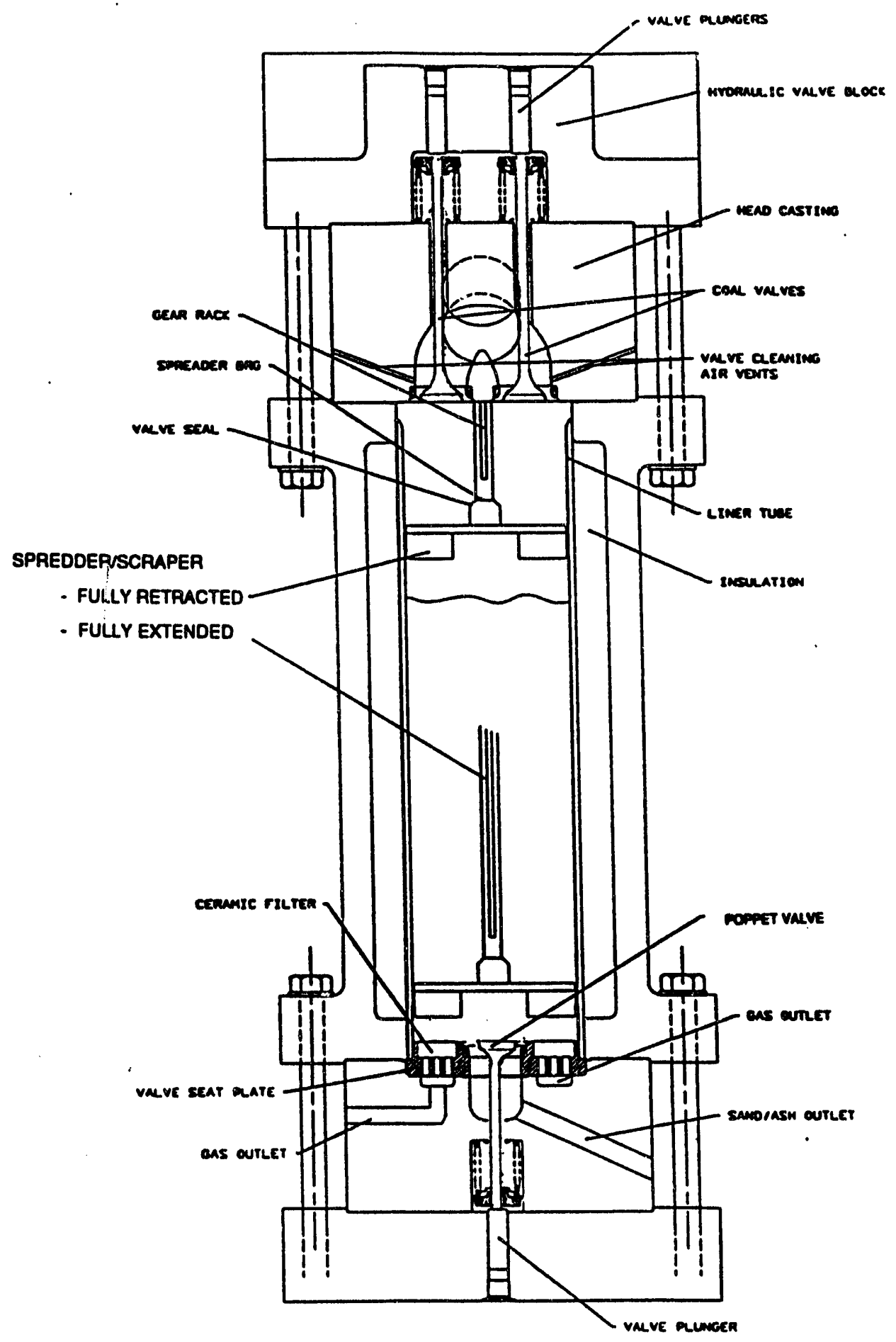

Figure 7. Multiple Valve Design Concept Cross Section 


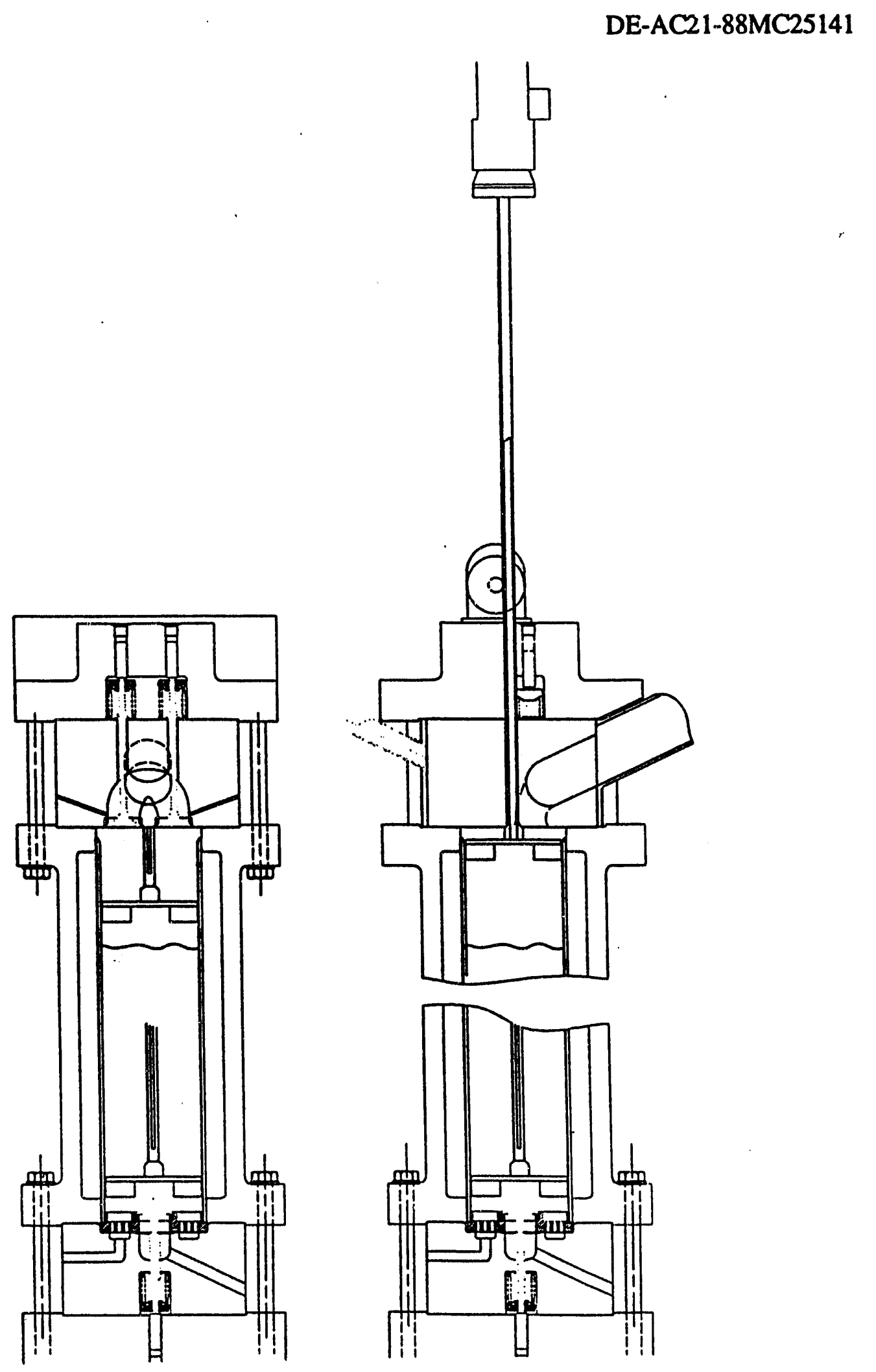

Figure 8. Multiple Valve Design Concept Scraper Mechanism 


\section{Guide Tube Design Concept}

The guide tube design concept (Figure 9) also has three gasification stations with fixed liners. Water is injected into the gasification chamber through a central hollow tube and spray nozzles. Cleaning and resupply are accomplished by lowering a guide tube assembly into the stationary pressure vessel.

A hydraulic cylinder mechanism raises and lowers the guide tube assembly (Figure 10). The guide tube assembly houses a rotating scraper and vacuum tube that remove ash and residue when lowered into the gasification chamber. Ash and residue are vacuumed through a side chute (not shown) in the guide tube. The gasification chamber is refilled with coal and filter media that are stored in separate vertical chambers located in the guide tube assembly. The premetered charges are emptied into the gasification chamber from the fill tube (Figure 9).

\section{Design Concepts Assessment}

The multiple valve design concept uses simple poppet valves for admitting air, coal, filter media and water and for removing the ash and residue. Operating pressure and valve springs keep the valves seated. The multiple valve design concept has the fewest large moving parts. It and the guide tube design concept are both more compact $\left(28.0 \mathrm{ft}^{2}\right.$ footprint) than the removable canister design concept.

The removable canister design concept was believed to be the best concept. It was incorporated into the integrated system design study based on the following conclusions:

- Removable canisters provide an inherent maintenance advantage: inspection, maintenance and replacement of canisters can occur without dismantling the fuel processor pressure vessels. Canisters can be rotated out of service as required to replace/refurbish the porous ceramic filters and inspect the canister tubes. Both the multiple valve and guide tube design concepts would require a pressure vessel tear-down for this purpose.

- Cleaning and refilling of the removable canisters takes place outside the pressure vessel. This minimizes mechanism exposure to high temperatures and pressures and should, therefore, enhance durability.

- The removable canister design concept does not expose its two pressure vessel seals to gasification residue which should contribute to a relatively higher level of reliability compared to the multiple valve and guide tube design concepts. 


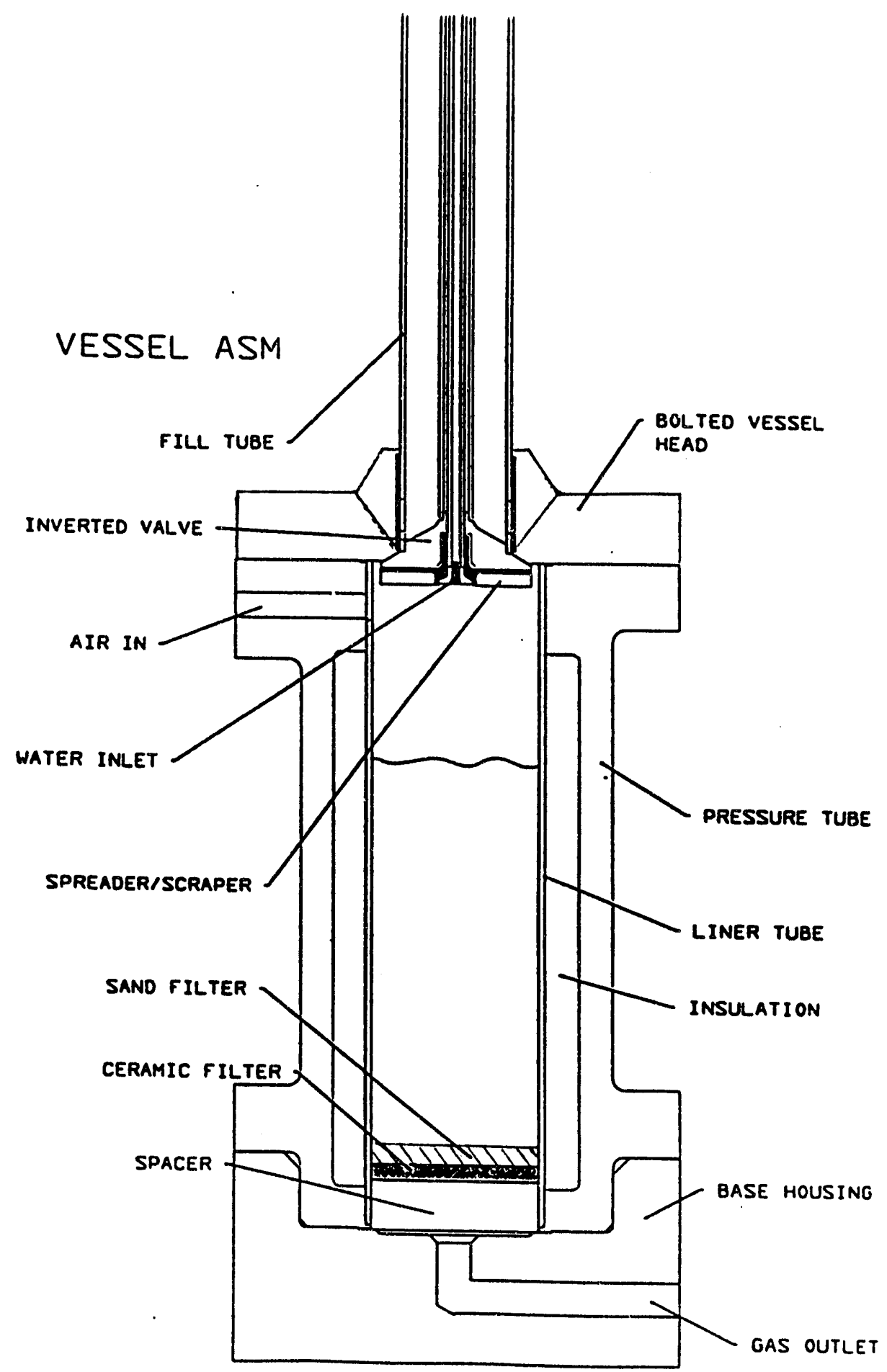

Figure 9. Guide Tube Design Concept Cross Section 
DE-AC21-88MC25141
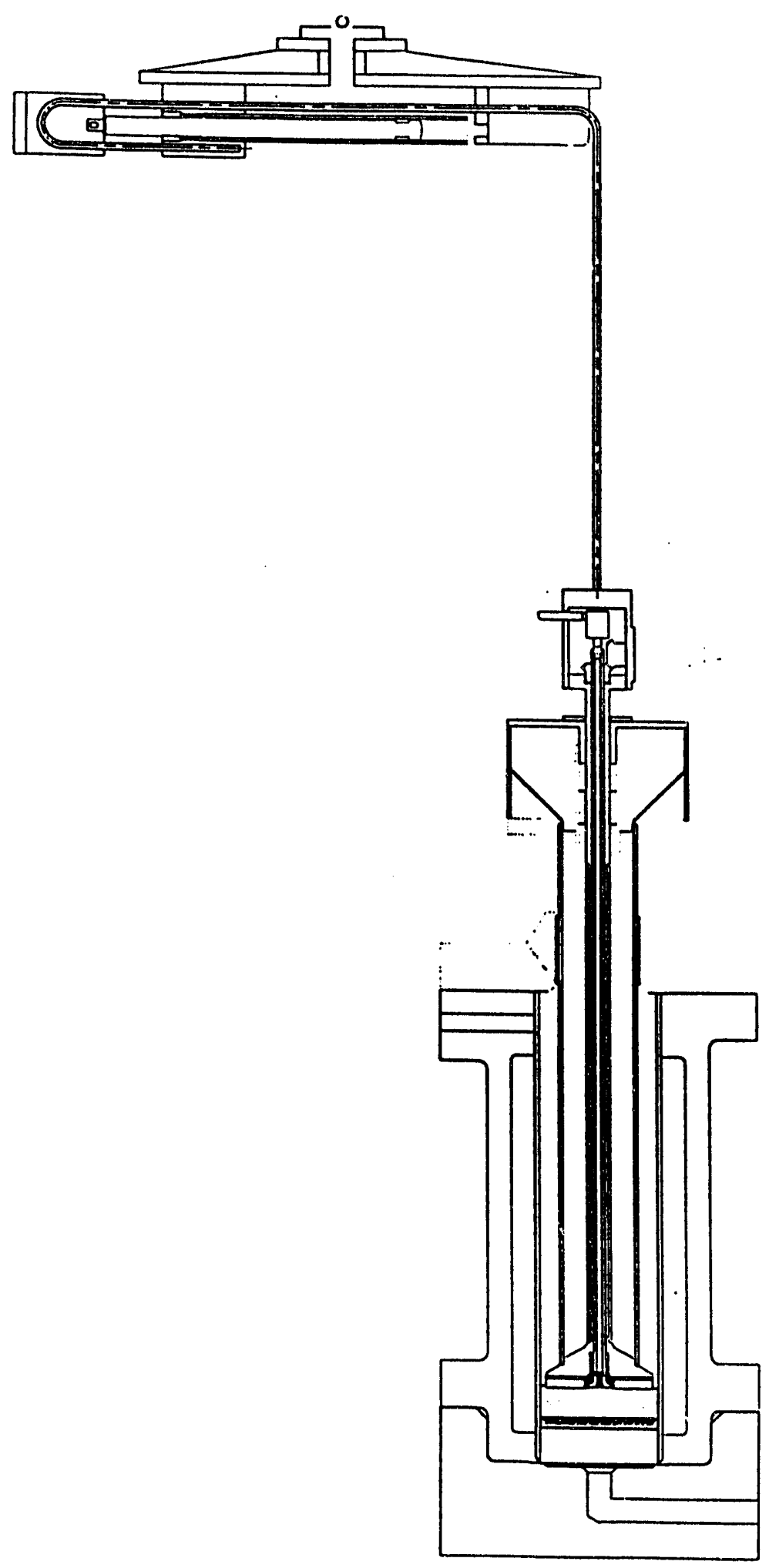

Figure 10. Guide Tube Design Concept Resupply Mechanism 


\section{Subtask 2.1.3 - Integrated System Design}

The objective of this subtask was to select a preliminary set of specifications for the integrated system and its commercial configuration. This was accomplished with the aid of an existing analytical system model, combustion and fuel processor rig test data, and preliminary layouts of the engine and fuel processor concepts in an EMD SD-45 locomotive chassis.

The original Statement of Work (SOW) called for a comprehensive integrated system design effort. The SOW was modified in September '91 (Mod A007) to include more extensive fuel processor rig testing and the contract Period of Performance was extended accordingly. The SOW was later modified again (Mod A010) due to a DOE limitation of funds. As a result, a major portion of the original integrated system design subtask was removed from the contract SOW. The following sections of this report cover the work completed on the remaining portion of the integrated system design subiask.

\section{Analytical System Model}

An existing first-order system performance model was used to investigate the interaction of fuel processor and engine design parameters. The fuel processor gasifier was treated as a steady, adiabatic, pressure reactor from which products emerge in thermochemical equilibrium. The engine was modeled using a Caterpillar cycle simulation program. The model was employed to investigate how system thermal efficiency (based on coal higher heating value) depends on fuel processor operating conditions, engine design, and the type of coal used in the fuel processor.

Figure 11 shows the effect of fuel processor pressure and temperature. The baseline system (Figure 1) thermal efficiency, based on raw coal higher heating value, is $32 \%$ at a fuel processor operating pressure of $3000 \mathrm{psi}$ and temperature of $1500 \mathrm{~F}$. There are small improvements in efficiency with lower pressures but large reductions in efficiency with lower temperatures. This means insulating the piping from the processor to the engine to reduce heat loss will be an important design consideration.

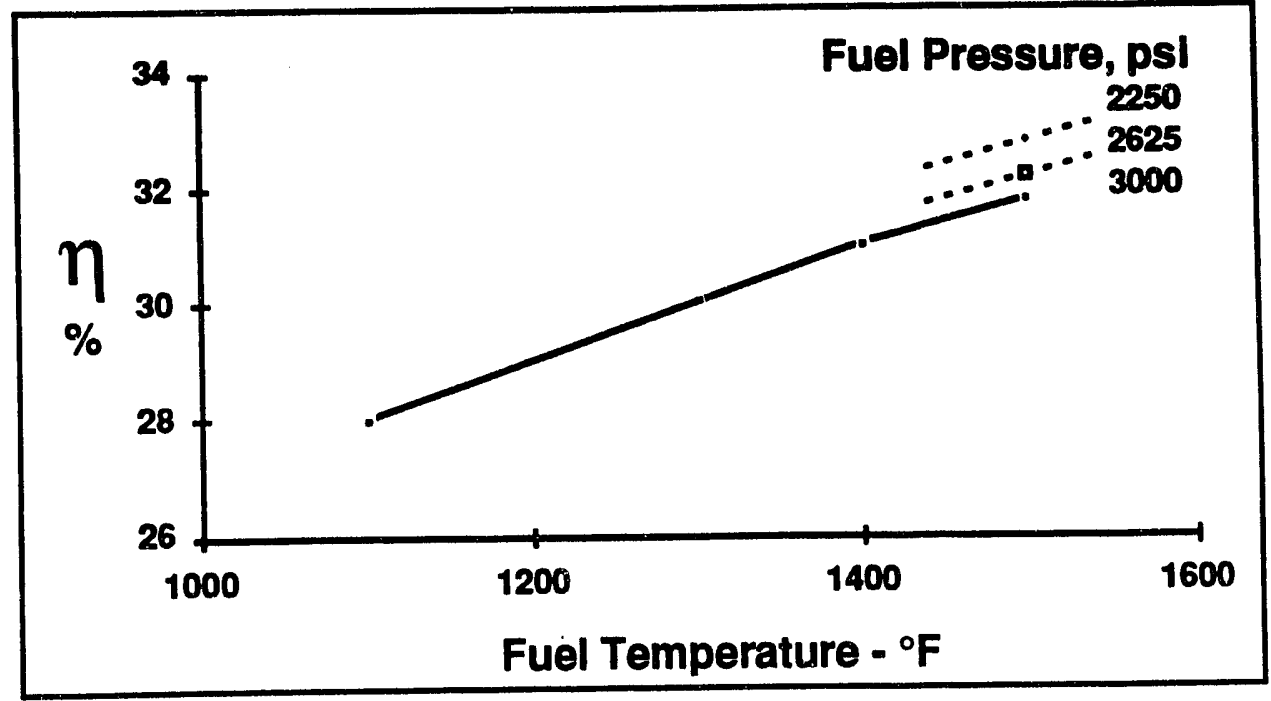

Figure 11. System Efficiency vs Fuel Temperature \& Pressure 
The predicted thermal efficiency of this concept also depends on the specific system configuration. Calculated efficiencies vary from the baseline case of $32 \%$ up to $39 \%$ (Figure 12) depending on the peak cylinder pressure and compression ratio of the engine; whether the engine is turbocharged or turbocompounded; and the degree to which heat is recovered from the engine exhaust. For example, a basic engine capable of $2300 \mathrm{psi}$ at a compression ratio of $15: 1$ (indicated by the arrow in Figure 12), such as the Caterpillar 3600 series, could be turbocompounded yielding a 3\% improvement in thermal efficiency over the baseline case.

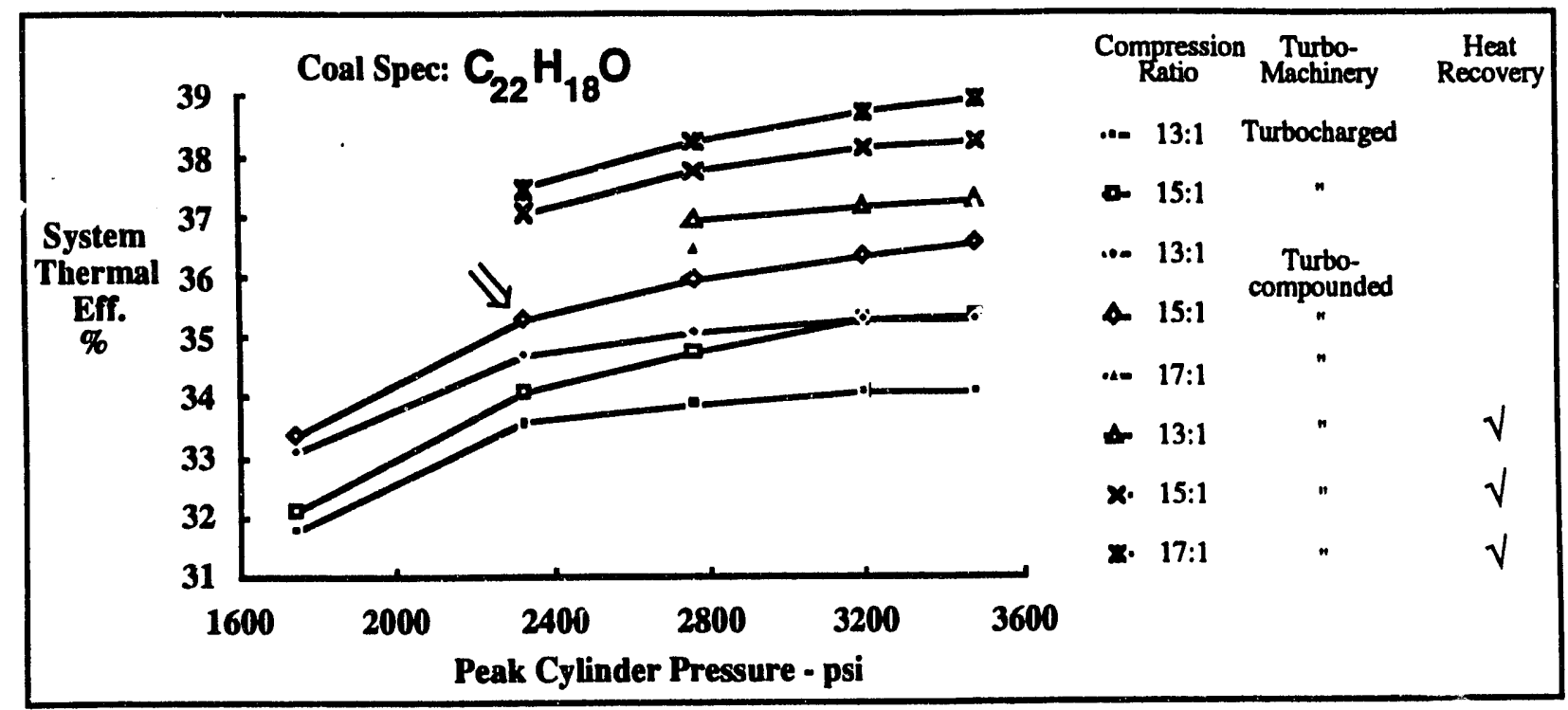

Figure 12. System Thermal Efficiency vs Peak Cylinder Pressure

System thermal efficiency is also a function of the fuel processor control parameters and the type of coal used. Figure 13 shows how efficiency varies with air-to-coal and water-to-coal ratios for three different fuel specifications.

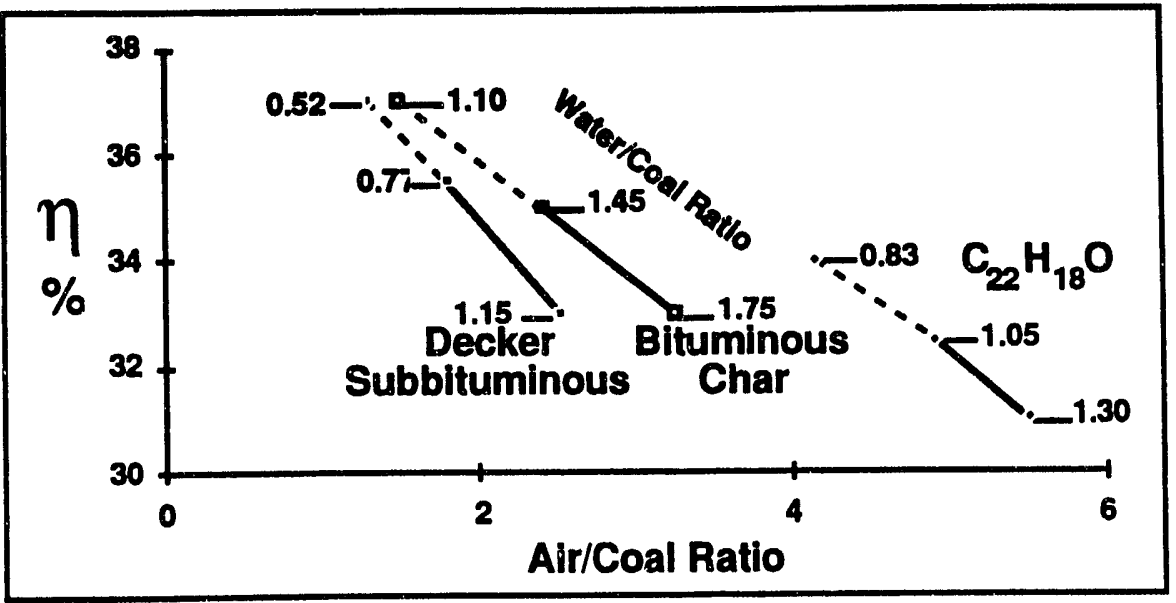

Figure 13. System Efficiency vs Air-to-Coal Ratio For Three Fuel Types 
Efficiency increases for lower values of air/coal ratio and water/coal ratio at a fixed coal gas exit temperature of $1500 \%$ for all three fuel specifications. The " $\mathrm{C} 22 \mathrm{H} 18 \mathrm{O}$ " is the coal specification for the baseline case and was used in the precontract concept study. The transition from the solid line to the dashed line is the point where the soot just begins to condense out.

Using the Decker Subbituminous coal specification in combination with the previously mentioned configuration (Figure 12: 2300 psi peak cylinder pressure, 15:1 compression ratio, turbocompounded) yields an overall system thermal efficiency of $37.1 \%$.

The engine/processor system simulation model was used to predict the formation of liquid and solid phases in the processor exit gas. Contours of overall system thermal efficiency were calculated as functions of fuel processor air-to-coal and water-to-coal ratios. Example results are shown in Figures 14 - 16 for three coal specifications.

The formation of liquid and/or solid phases occurs at ratios below the Condensation lines in Figures 14 - 16. Based on current knowledge, the system operating range can be taken as confined to above the Condensation lines and below the lines of constant $1.500 \%$ exit gas temperature. An efficient means for utilizing the thermal and chemical energy contained in the liquid/solid phases would have to be devised in order to achieve the system thermal efficiencies shown below the Condensation lines.

The air and water to coal ratios required to avoid condensation of solids and liquids vary widely between coal types. The Decker subbituminous (Figure 15) has the smallest zone in which condensates form because it contains more hydrogen and oxygen, relative to carbon, than the other two coal types. The Decker coal thus requires a lower flow rate of air and water per unit mass of coal to avoid condensation.

Exit gas temperature is primarily a function of the raw coal heating value and to a lesser extent of the coal composition. The bituminous char (Figure 16) produced the highest exit gas temperature because the gasifier was assumed adiabatic, energy was conserved from inlet to outlet and this coal type had the highest heating value.

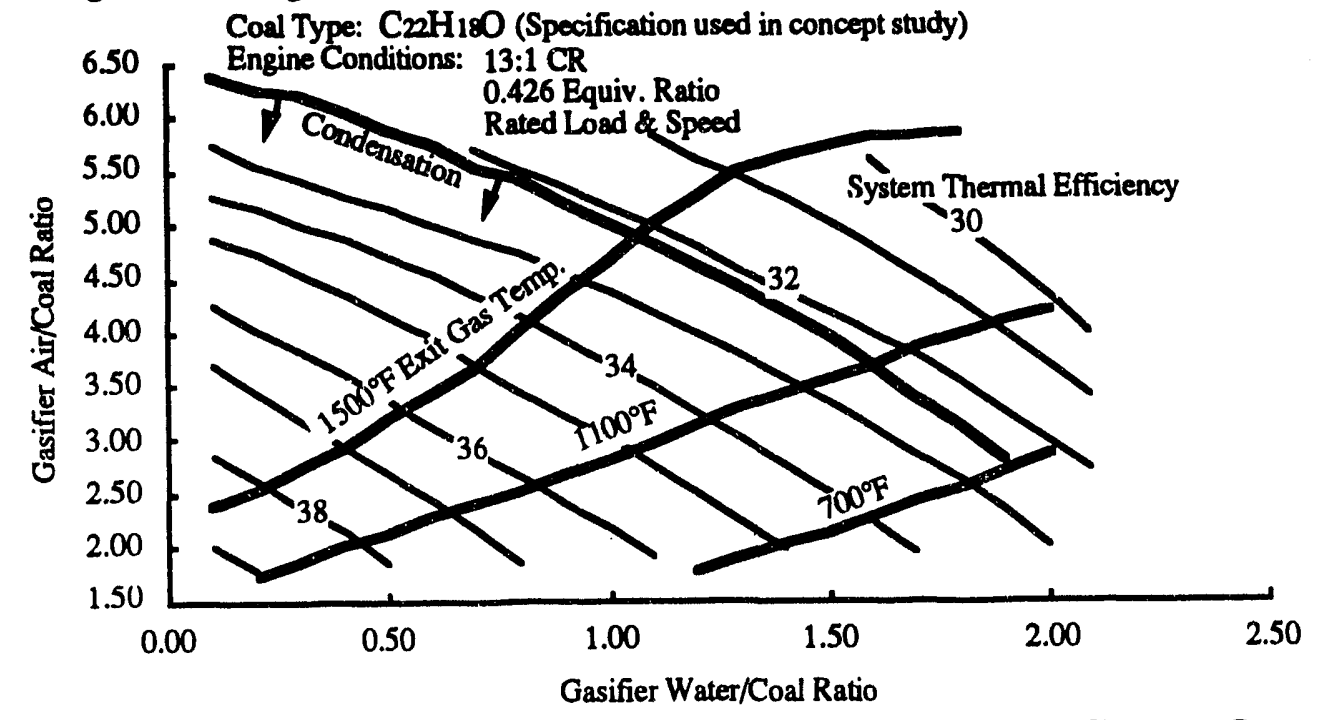

Figure 14. Coal-To-Air vs Water-To-Coal Ratio: $\mathrm{C}_{22} \mathrm{H}_{18 \mathrm{O}}$ - Concept Study Coal Specification - 


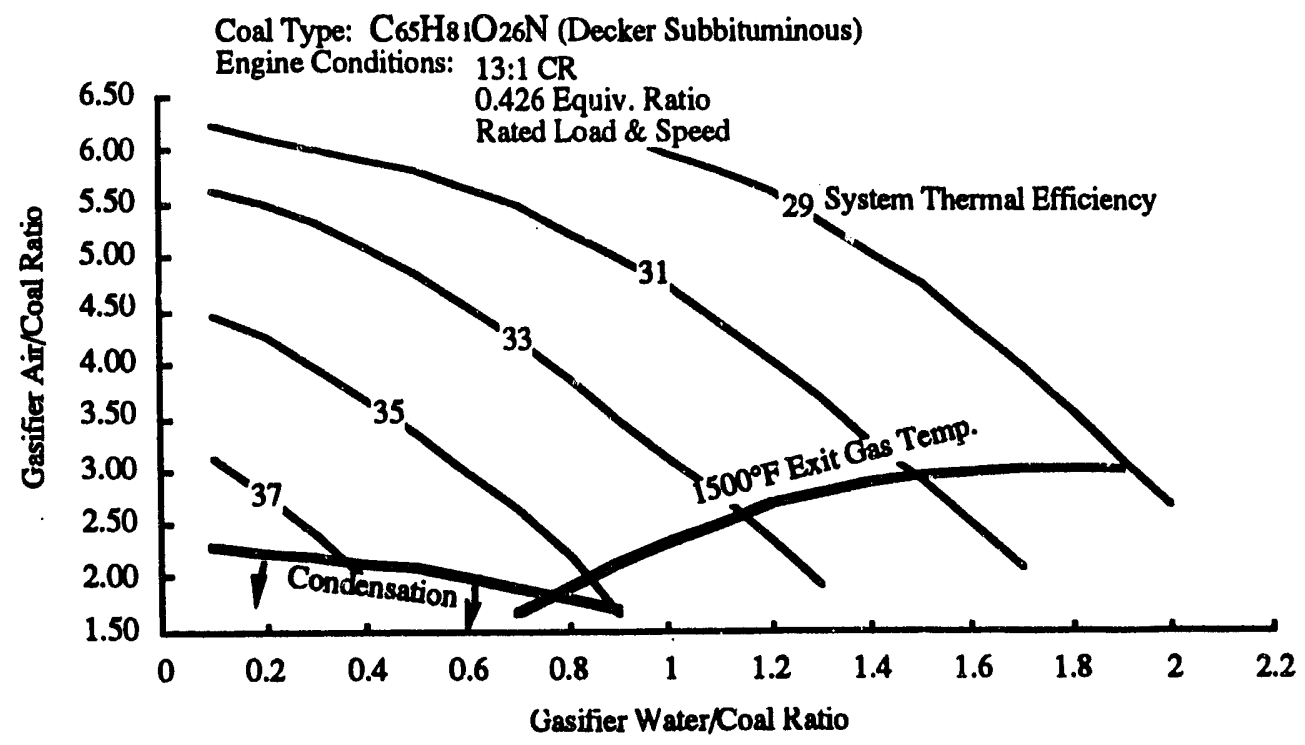

Figure 15. Coal-To-Air vs Water-To-Coal Ratio - Decker Subbituminous Coal -

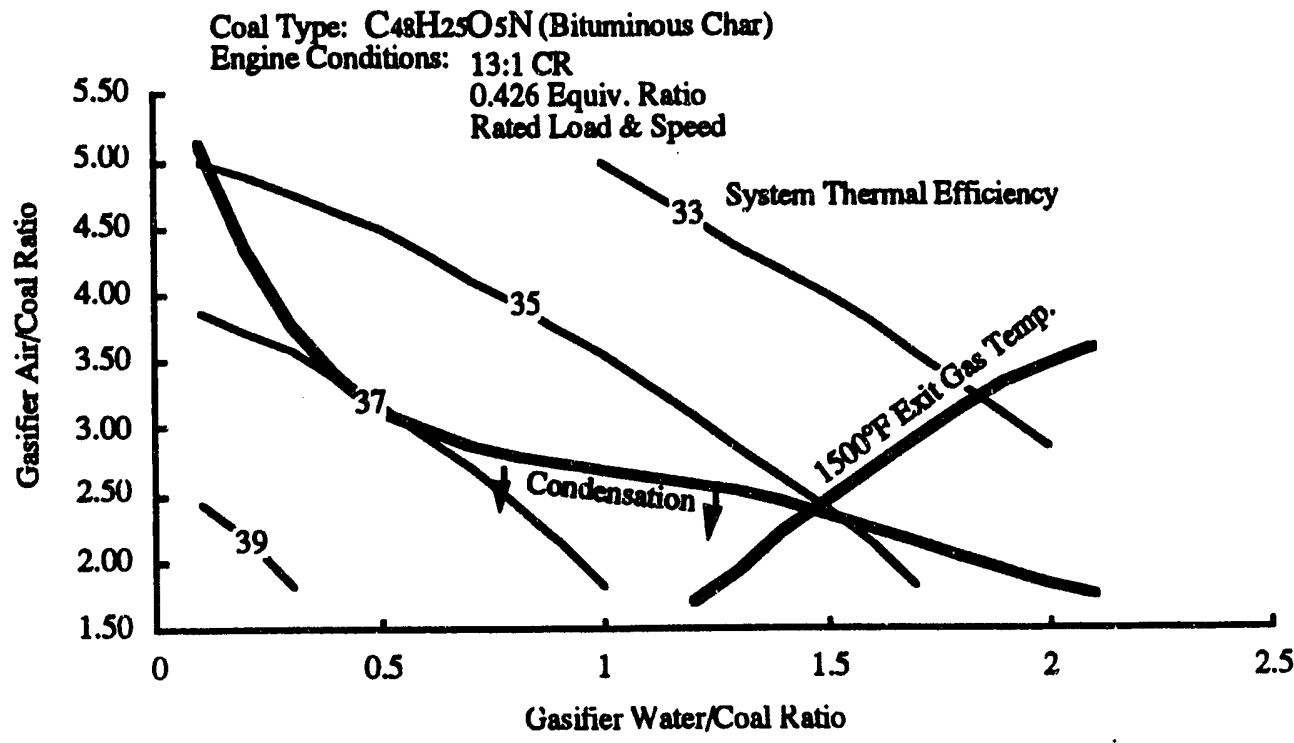

Figure 16. Coal-To-Air vs Water-To-Coal Ratio - Bituminous Char -

The plots in Figures 14 - 16 are combined in Figure 17. The Decker coal produced the highest system efficiency within it's range of practical operating conditions, e.g., for exit gas temperatures $\leq 1500 \%$ and no condensation. Because it has a high percentage of hydrogen and oxygen relative to carbon, condensation only occurs at very low air and water flows. As a consequence of its relatively low heating value, it also produces a relatively low exit gas temperature. 


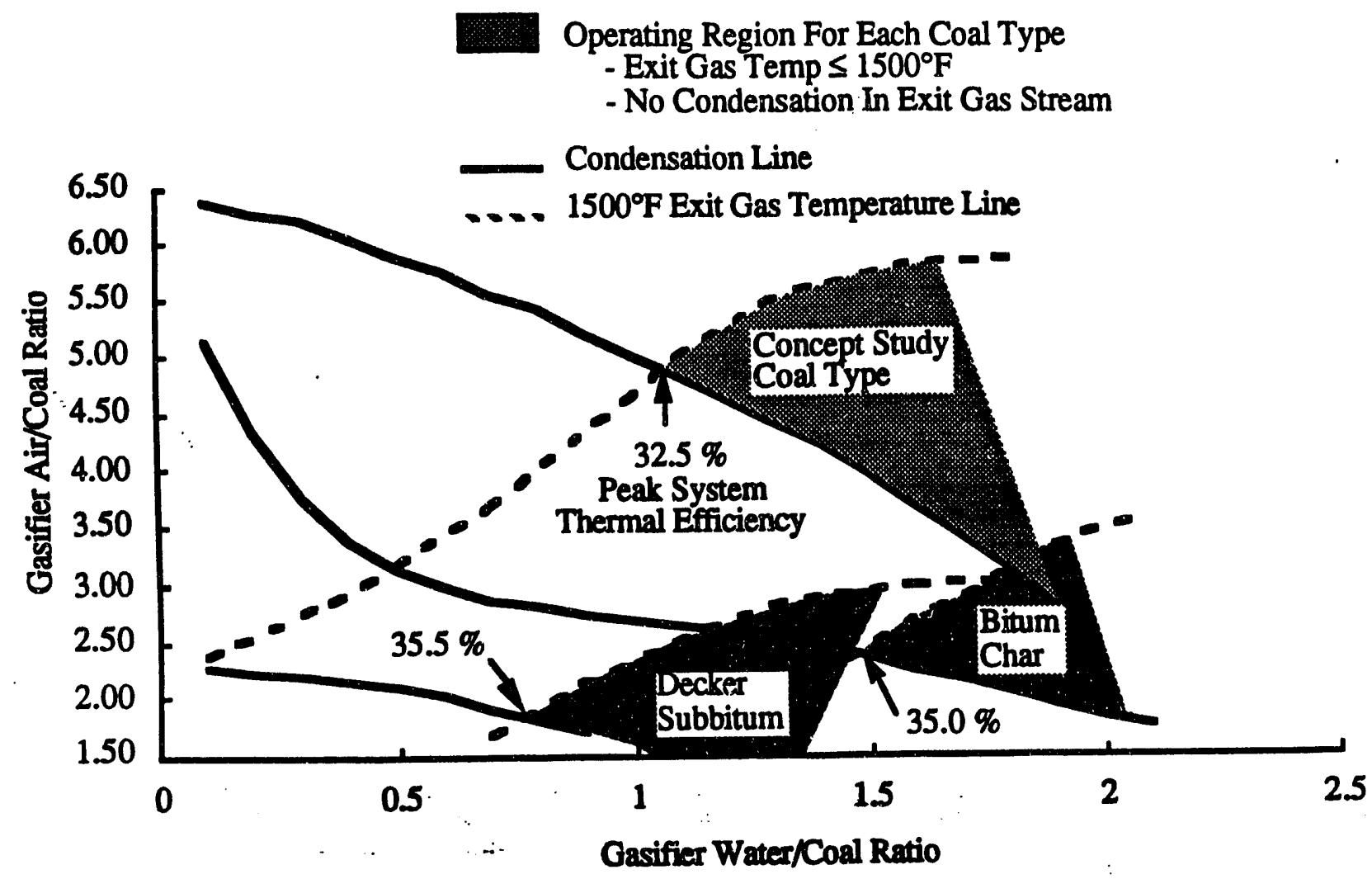

Figure 17. Practical Operating Regions For Three Coal Specifications

These calculations are based on the assumption that the fuel processor is adiabatic and that the gasification reactions have reached thermochemical equilibrium. Both assumptions are somewhat unrealistic but they do illustrate that coal type and fuel processor control parameters can have a significant effect on overall system thermal efficiency.

The analysis model predicts that the overall system thermal efficiency is about $35 \%$ and that the engine power output depends on how the engine is configured and on what type of coal is used in the fuei processor. The net power generated is directly related not only to the type of coal used but also to the rate at which the coal can be gasified and to the physical dimensions of the fuel processor gasification chamber (Figure 18).

Figure 18-a shows, for example, the relationship between net power output and coal consumption rate for a given engine configuration and two coal types. The internal diameter of the gasification chamber required to gasify coal at any particular coal consumption rate depends on the specific gasification rate (Figure 18-b). Specific gasification rates, as determined from fuel processor rig tests, depend primarily on coal type and inlet air flow rate to the gasifier (Figure 18-c). For purposes of this concept analysis, the test data shown in Figure 18-c are assumed to be independent of gasifier size. The gasification time per canister also depends on the specific gasification rate as well as the length of the canister (Figure 18-d). 
I.
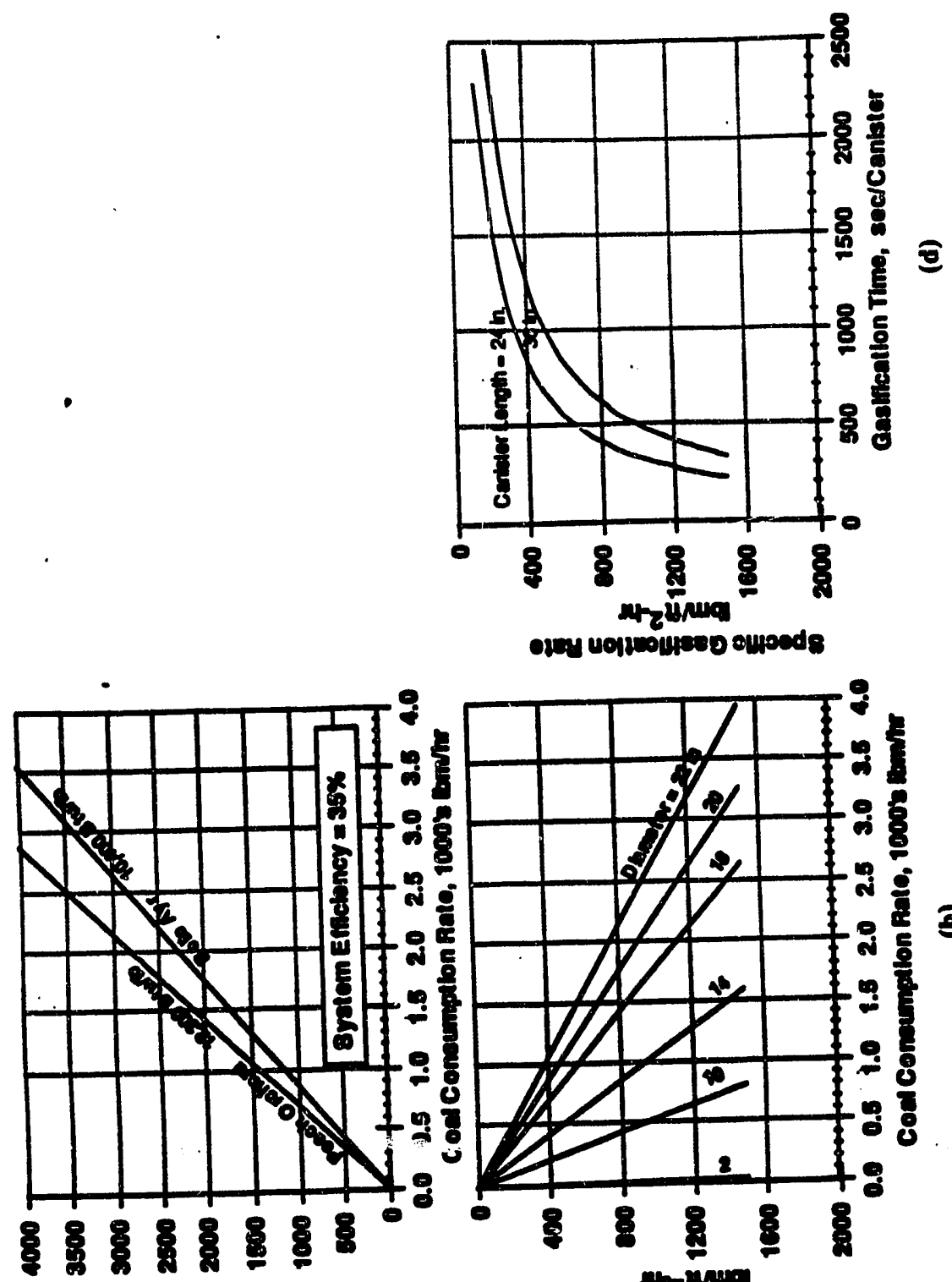

ch comper

a
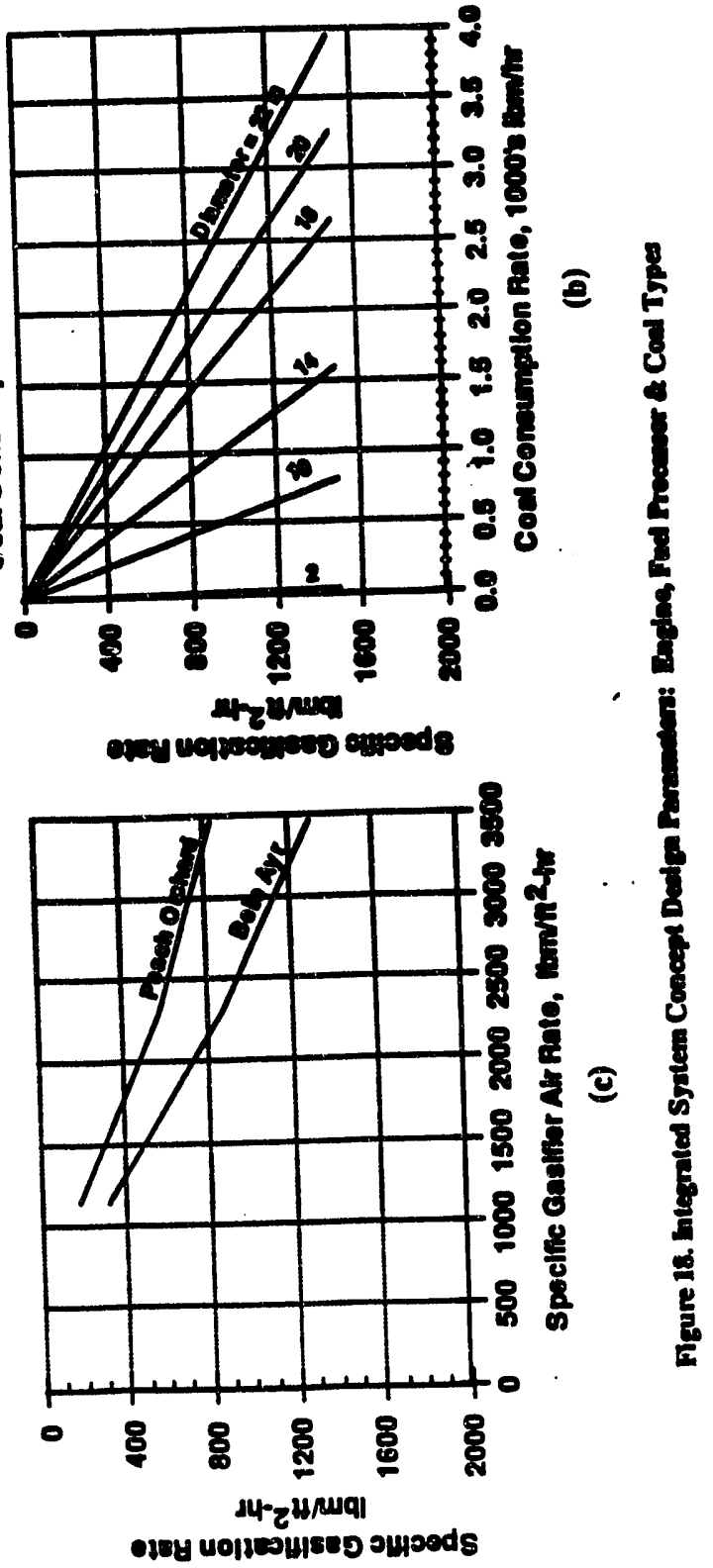


\section{Air Compressor Concepts}

The compressor subsystem supplies high pressure air to the gasifier at 3000 psi with a maximum rate of $150 \mathrm{lbm} / \mathrm{min}$. The first stage is an exhaust-driven centrifugal compressor with an outlet pressure of $44.5 \mathrm{psi}$. The remaining compression ( 44.5 to $3000 \mathrm{psi}$ ) can be accomplished in three or four additional stages.

A review of the literature indicated that the second stage could be performed by either a rotary (screw or axial flow) or a reciprocating piston compressor (Yeaple, Frank, "Packaging Compressed Air", Design Engineering, July 1981). The remaining stages would require reciprocating piston compressors. To simplify the compressor drive mechanism and the compressor contrul, reciprocating compressors were selected for the the second and higher stages. Commercially available reciprocating compressors were sized to complete the air compression up to the 3000 psi gasifier operating pressure. Commercially available compressors, typically $32^{\prime} x$ $23^{\prime} \times 12^{\prime}$, however, are much too large for locomotive applications.

Utilization of engine cylinders to compress the air was investigated as a possible means of reducing compressor size requirements. This would entail increasing the locomotive engine size from twelve to sixteen cylinders (Caterpillar 3616 vs 3612). The extra four cylinders would be used to compress the air in four stages. Comparison of this concept to current commercial compressor technology indicates that the arrangement is reasonable. However, piston speeds are such that volumetric efficiency, using current technology compressor valves, is significantly lower. To utilize this approach, either improved valving would have to be developed or lower volumetric efficiency would have to be accepted. An economic vs performance tradeoff study would be required to resolve this issue and this was beyond the scope of this contract.

Heat exchangers will be required to cool the air between compression stages. Specific heat exchanger design concepts were not investigated but the conditions needed to select sizes of commercially available heat exchangers are listed in Table 4.

Table 4. Compressor Heat Exchanger Conditions

\begin{tabular}{cccc}
\hline Heat & Discharge & Inlet Temperature & Outlet Temperature \\
Exchanger \# & Air Pressure & q & F \\
& psi & 340 & 145 \\
1 & 59.2 & 325 & 120 \\
2 & 142.5 & 325 & 120 \\
3 & 410.8 & 325 & 120 \\
4 & 1151.6 & & \\
\hline
\end{tabular}

\section{System Control Concept}

The system control concept is comprised of an overall system supervisory module and four submodules, one each for the engine, the fuel processor, and the resupply mechanism, plus a module for diagnostics and display of system status (Figure 19). The supervisory module monitors overall system performance; provides the logical interface between the engine, fuel processor, and resupply subsystems; and provides for fine tuning of the engine, fuel processor, and resupply mechanism subsystem controllers. 
DE-AC21-88MC25141

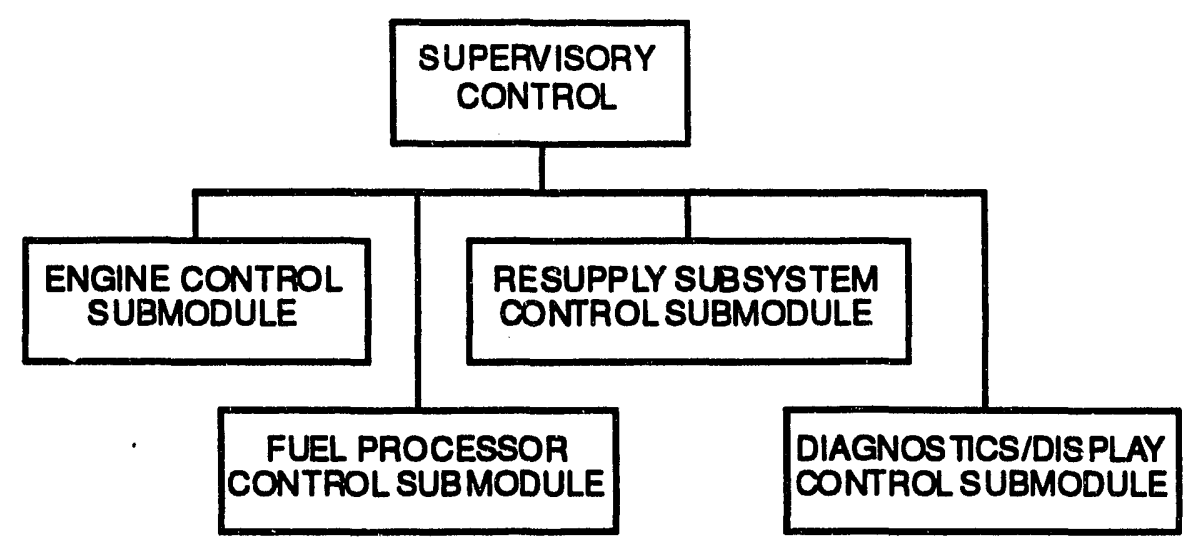

Figure 19. System Control Concept Modules

Hardware exists for some of the elements of this system control concept. Caterpillar produces a control for its 3500 Series locomotive engines, for electric propulsion generators, and for 3600 Series spark ignited natural gas engines. The engine concept control (Figure 20) would be a modification of the Caterpillar natural gas engine control shown in Figure 21.

A preliminary investigation of the fuel processor control requirements suggests that at least nine inputs and ten outputs would be necessary for the fuel processor control submodule as indicated in the schematic shown in Figure 22. Figure 23 shows a similar level schematic for the resupply control submodule. While the details of these information flows have not been identified, they do give a preliminary indication of the types of sensors and actuators that w'1l be required for this control concept.

In general, the system control can be specified. Design of the hardware and control logic algorithms does not present any obviously insurmountable technical barrier. The technical challenge could well be obtaining acceptable stability for this complex control. Further system analyses are required to identify the magnitude of this uncertainty. Adapting Caterpillar's proven, state-of-the-art control technology to meet the requirements of the coal fueled diesel locomotive concept would require further development. 


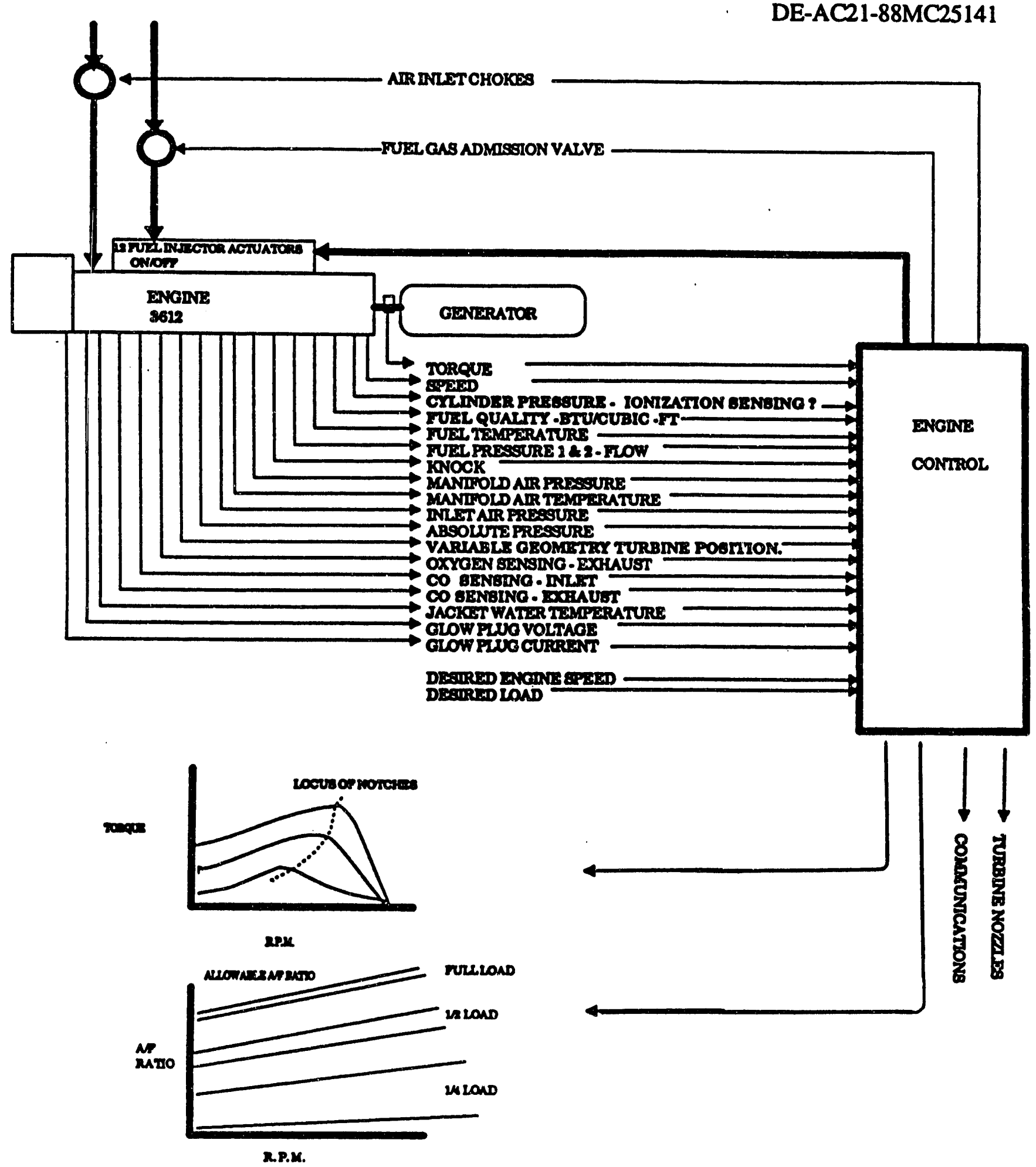

Figure 20. Engine Control Concept 


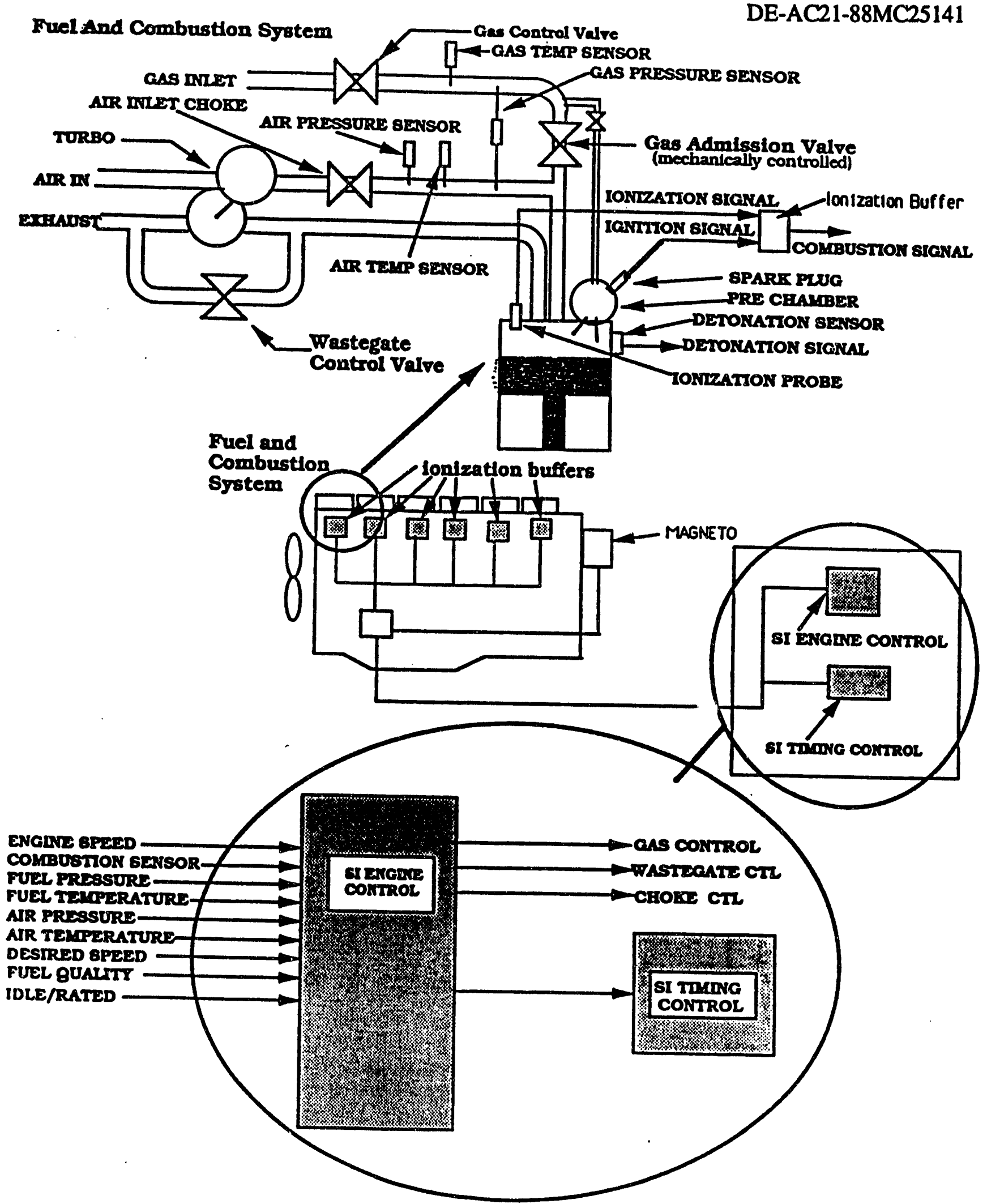

Figure 21. Caterpillar 3600 Series Spark Ignited Natural Gas Engine Control 


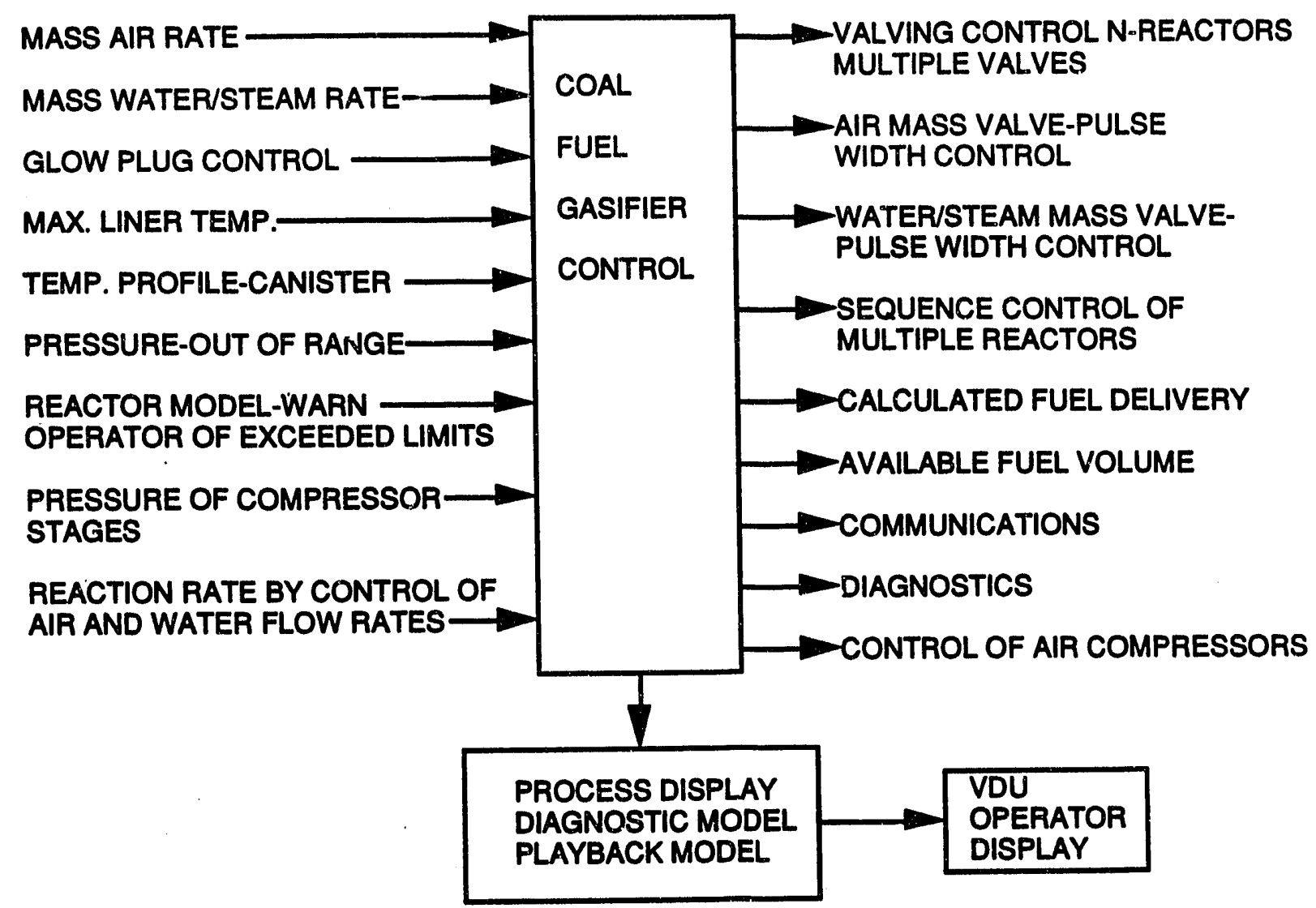

Figure 22. Fuel Processor Control Concept

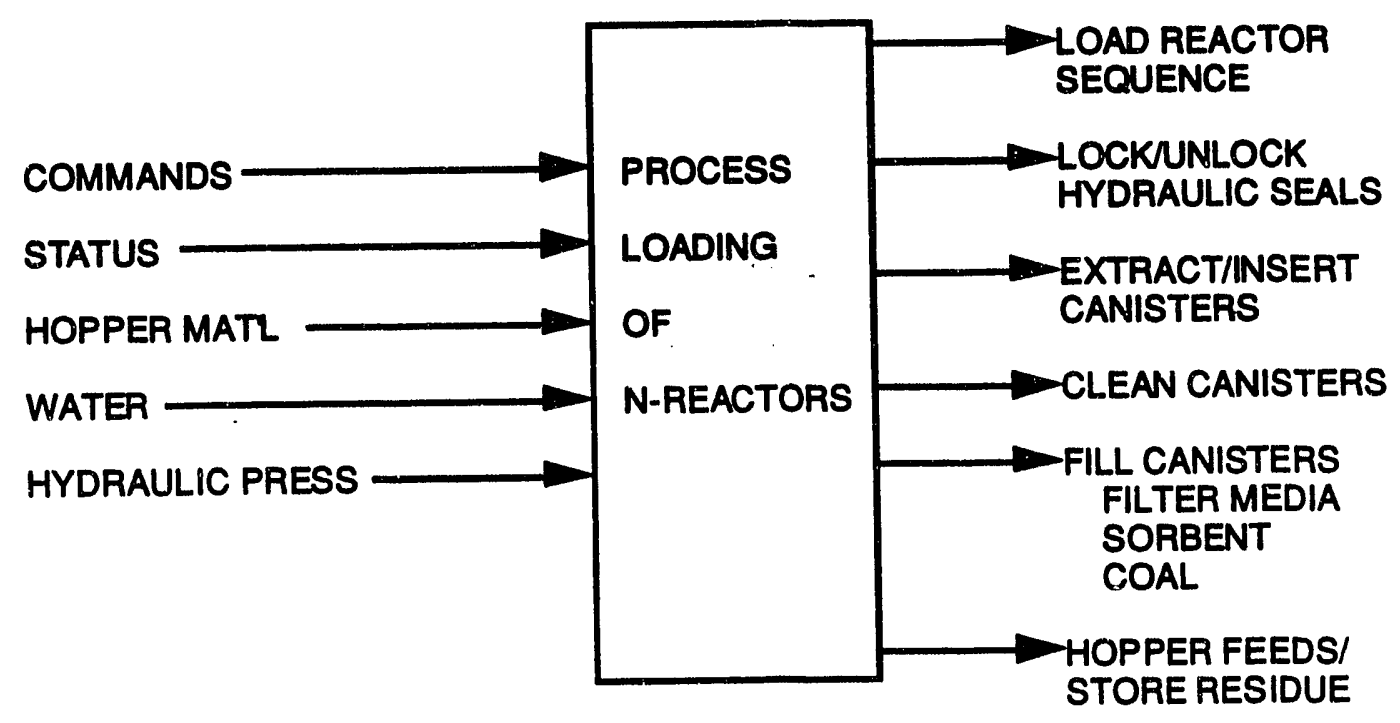

Figure 23. Resupply Control Concept 


\section{Locomotive Installation Concept}

A layout of the system concept, based on the preliminary analyses to date, is shown in Figure 24. Equipment shown at the rear (flywheel end) of the engine (toward the front of the locomotive) includes the generator and the traction motor blower. Dynamic brake grids are located above the engine. At the front of the engine are auxiliary oil coolers, an auxiliary coolant tank, the train brake air compressor and the radiators. The volume needed for the fuel processor is shown crosshatched.

As proposed, the fuel processor does not quite fit entirely within the confines of the locomotive car body height or width. There are many combinations of canister height and diameter which could supply the necessary amount of coal gas to fuel the engine. The concept shown is a two-abreast by two-inline arrangement of the gasification stations. A four-inline configuration, not investigated in any appreciable detail, would significantly reduce width requirements but would complicate shuttling the canisters between the gasification stations and the resupply station.

The following hardware may require relocation:

- Train brake air compressor (possibly eliminated by bleeding off gasifier compressed air)

- Auxiliary engine coolant tank

- Auxiliary engine coolers

- Electrical cabinets and related equipment (not shown)

- Additional items may be identified with a more detailed layout investigation.

The primary alternative for supplying coal, sulfur sorbents and granular filter media to the fuel processor would be an air blower subsystem. This would be similar to many bulk transporting systems used to fill covered hopper cars. Other methods used to transfer coal include augers, belt conveyors and reciprocating plate feeders. The important advantage of the air blower system is that the connection between the locomotive and the tender car could be flexible, a requirement for negotiating curves. Removing the residue from the fuel processor could be accomplished with a similar arrangement. 


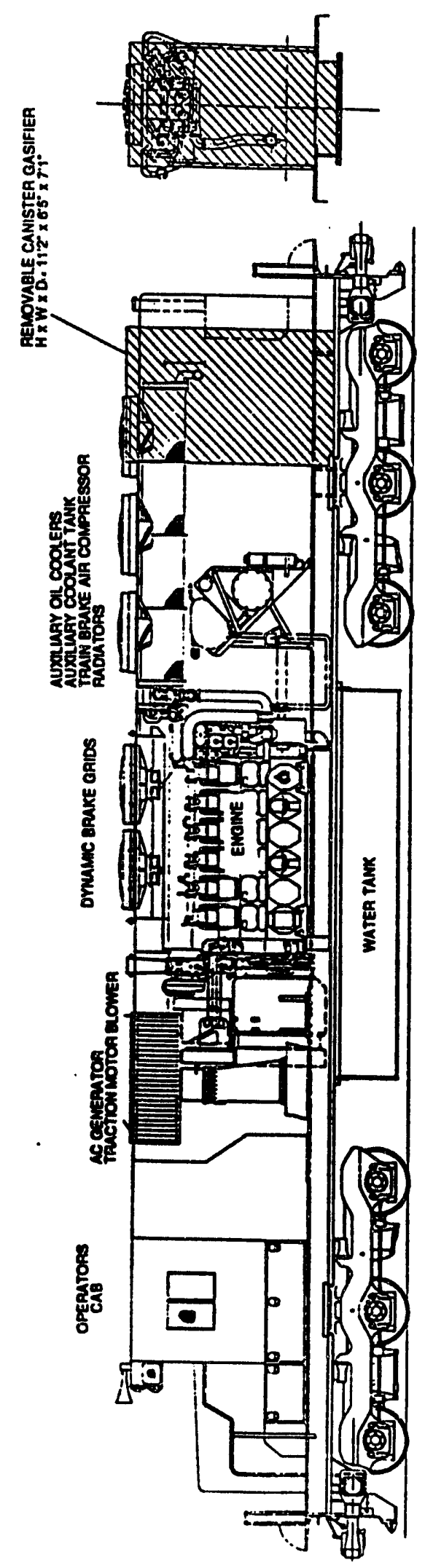

Figure 24. Layout of System Concept Design: Locomotive Installation 
DE-AC21-88MC25141

\section{SUMMARY}

The engine concept can be derived from a Caterpillar 3600 series production engine with modifications to the cylinder head, fuel injection system and electronic engine control. The cylinder head would require modifications to the inlet and exhaust valves and ports and the addition of an insulated fuel gas passage. Additional research and development is required on the coal gas injector to reduce check seating velocity. The concept engine control can be derived from a Caterpillar 3600 series spark ignited engine control. Further combustion system research and development are required to determine an optimum flow area split between the inlet and exhaust valves.

The fuel processor concept design incorporates four gasification stations with removable canisters and two resupply stations. The gasification station pressure vessel configuration is derived from the smaller scale design developed for fuel processor rig testing. More research and development are required to improve performance of the atomizing water injector. Improved performance is necessary to permit gasifying coal at faster rates while holding maximum combustion temperatures to below the thermal/structural limit of the canister. More research and development are required to establish the durability of the canister seals, ceramic filters, breech locking mechanism and gas outlet disconnect device. The feasibility of the transfer mechanisms in the resupply stations remain to be established.

A four-stage reciprocating compressor configuration for this application needs to be identified to significantly reduce the compressor subsystem size to well below that of commercially available equipment. More research and development would be required to establish the feasibility of using four cylinders of a Caterpillar 3616 engine for this purpose. The primary challenge would be development of fast-acting, high-volumetric efficiency compressor valves.

The system control concept can be derived from a Caterpillar 3500 series locomotive engine control. A preliminary list of sensors and actuators were identified. Further research and development are required to assess control stability and to provide more definitive specifications for sensors and actuators.

Packaging the system concept within the space available on a representative line-haul locomotive (EMD SD-45) appears feasible. Some rearrangement of existing equipment is necessary. A mechanism for delivering bulk materials to and from the tender car needs further investigation although the proposed air-blower subsystem appears feasible.

The results of this abbreviated concept study are extremely encouraging. However, additional fullscale component research and development are recommended before undertaking a full-scale integrated system demonstration. 

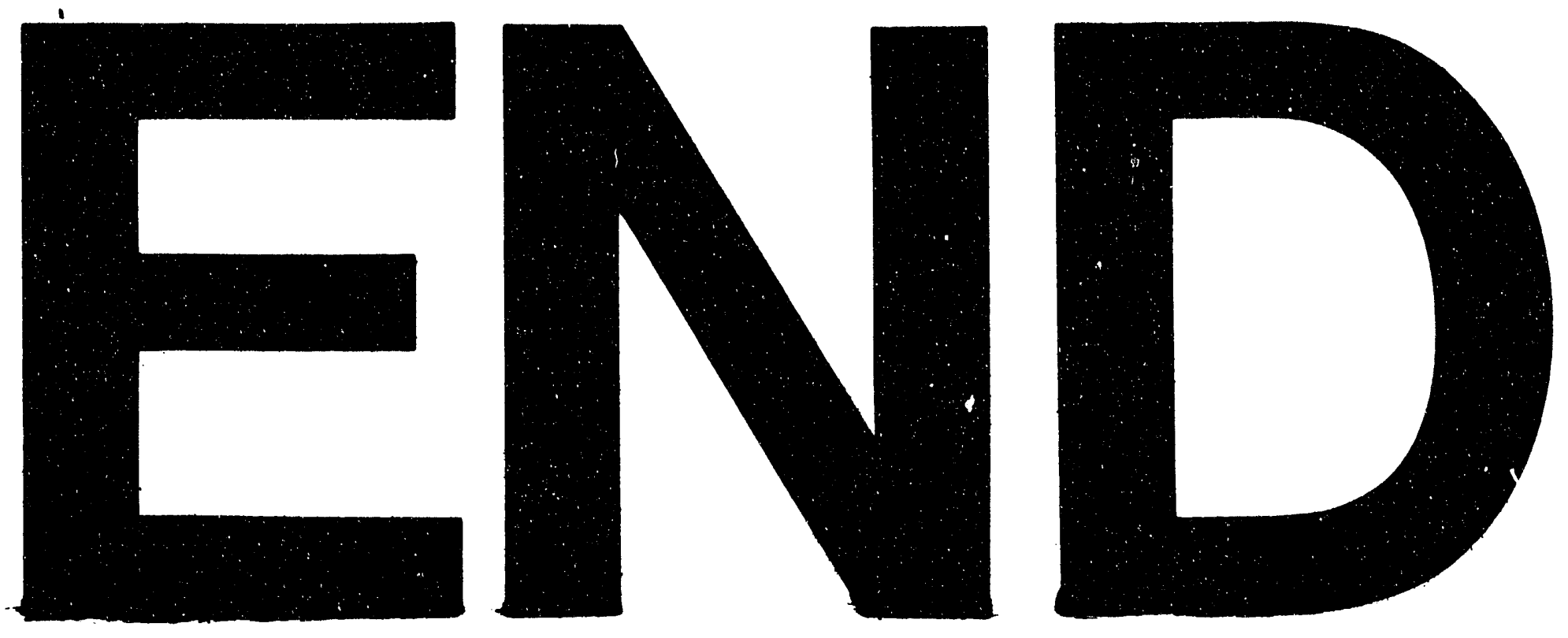

10

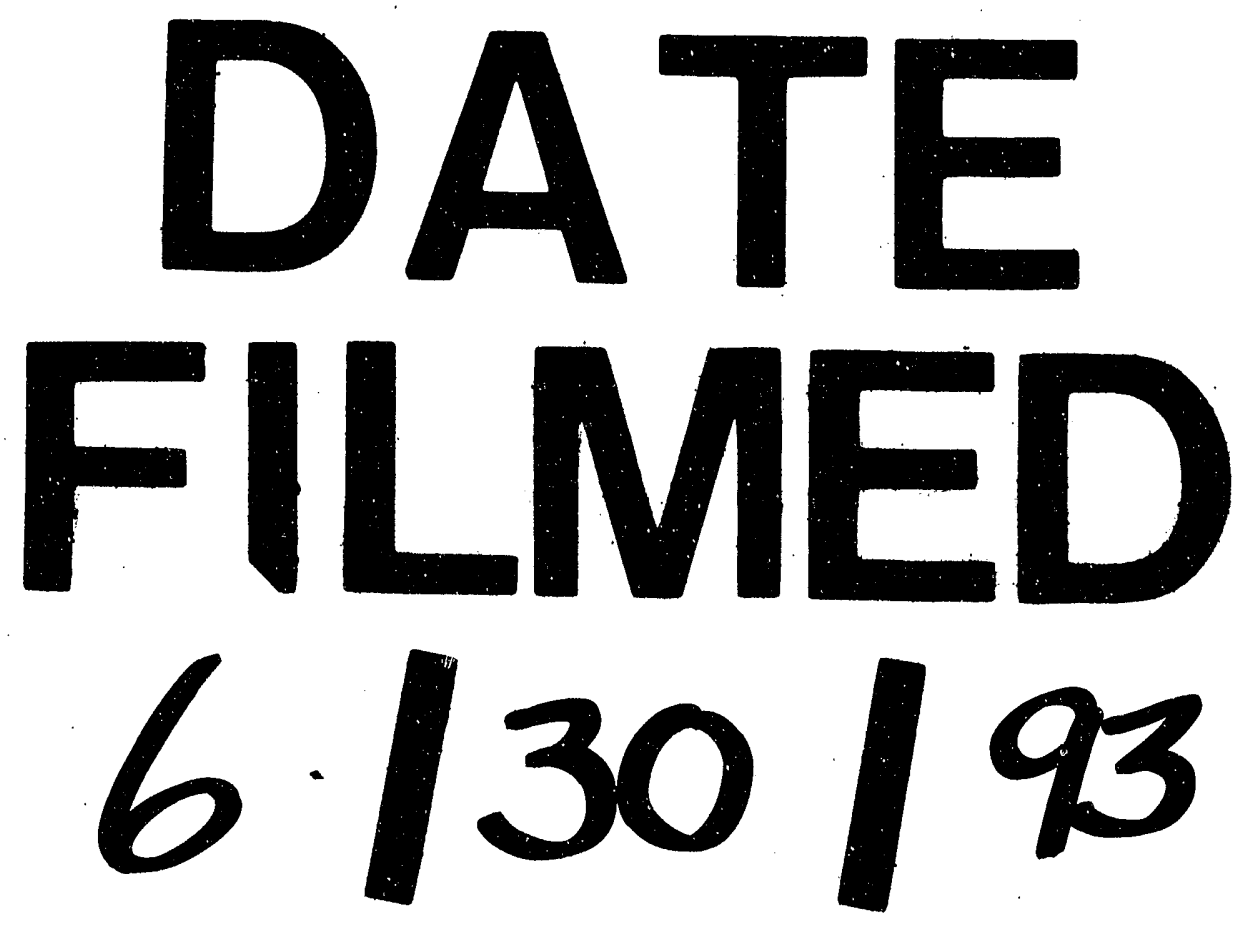


